\title{
UNSOLICITED BIDS FOR GOVERNMENT FUNCTIONS
}

\section{NOLAN BEDERMAN and MICHAEL TREBILCOCK*}

This article develops the case for designing a process to encourage and evaluate unsolicited bids for privatization or contracting out of government functions. The authors argue that conventional government procurement practices are unlikely to uncover or reveal all potentially desirable opportunities for privatization or contracting out, given informational constraints, search costs, and bureaucratic and political disincentives operating on public sector agents. Thus, there is a strong case for reversing the burden of initiative with respect to alternative modes of delivery of public goods or services.

The article develops a private sector analogy for unsolicited bids for government functions - the market for corporate control. The market for corporate control, i.e. unsolicited takeover bids, reduces agency costs by better aligning the interests of shareholders and managers who face incentives to manage corporate assets efficiently or risk job displacement through unsolicited bids. Where such bids are successful, assets are likely to be moved to higher valued uses. Unsolicited bids for privatization or contracting out of government functions are likely to serve a similar function in the public sector.

In designing a process for encouraging and evaluating unsolicited bids for government functions, it is important that such a process (a) promote competition without stifling innovation by second movers free riding on innovative ideas initially proposed to government by other private sector agents; (b) ensure transparency of the process; and (c) locate institutional responsibility for dealing with unsolicited bids in a central agency of the government in order to overcome localized bureaucratic or political vetoes.

The authors develop three variants of a process for encouraging and evaluating unsolicited bids: (a) a modified competitive process; (b) a Request for Conceptual Proposals; and (c) monitored solesourcing.
Les auteurs proposent l'élaboration d'une procédure visant à promouvoir et à évaluer des soumissions spontanées de privatisation ou d'impartition des fonctions gouvernementales. Ils estiment que le processus conventionnel des achats ne permet pas véritablement de repérer ou de révéler toutes les possibilités de privatisation ou d'approvisionnement désirables, en raison de contraintes informationnelles, des frais de recherche, et des contre-incilations bureaucratiques et politiques exercées sur les agents publics. Il paraît donc impératif de renverser le fardeau de l'initiative concernant des modes parallèles de fourniture de biens ou de prestation de services publics.

Dans cette optique, les auteurs établissent une analogie avec le secteur privé - le marché de la prise de contröle d'entreprises. Ce marché (c.-à-d. les offres d'achat spontanées) réduit les coûts d'encadrement en assurant une meilleure adéquation des intérêts des actionnaires et des dirigeants qui sont motivés à gérer efficacement les actifs de la société sous peine de se voir évincés par d'autres soumissionnaires. Quand des offres plus avantageuses sont retenues, la gestion des ressources de l'entreprise s'en trouve en général optimisée. Il est probable que les offres spontanées de privatisation ou d'impartition des fonctions gouvernementales rempliraient la même fonction dans le secteur public.

Tout processus de promotion et d'évaluation de ce type doit a) favoriser la concurrence en se gardant d'étouffer l'innovation, ce qui pourrait arriver si le soumissionnaire suivant se contentait d'exploiter les idées novatrices initialement proposées au gouvernement par d'autres agents du secteur privé; b) assurer la transparence du processus; et c) confier les responsabilités institutionnelles $d u$ traitement des soumissions $\dot{a}$ un organisme gouvernemental central, pour faire échec aux obstacles politiques ou bureaucratiques localisés.

Les auteurs proposent trois variantes d'un tel processus : a) un processus d'appel d'offres modifié, b) une demande de propositions conceptuelles; et c) une demande contrôlée du type "fournisseur exclusif ".

Nolan Bederman is a joint LL.B.-M.B.A. student at the University of Toronto. Michael Trebilock is Professor of Law and Director of the Law \& Economics Program at the University of Toronto. This study was jointly sponsored by the Canadian Council for Public-Private Partnerships and the Centre for the Study of State and Market, University of Toronto, Faculty of Law. 
TABLE OF CONTENTS

I. INTRODUCTION . . . . . . . . . . . . . . . 904

II. CURRENT GOVERNMENT PROCUREMENT PRACTICES ... 905

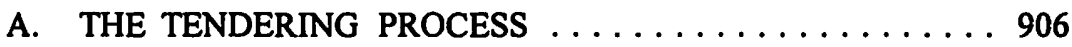

B. THE REQUEST FOR PROPOSALS (RFP) AND

REQUEST FOR QUALIFICATIONS (RFQ) . . . . . . 907

C. SOLE-SOURCING ................... 908

D. CONSTRAINTS ON IDENTIFYING

PUBLIC-PRIVATE PARTNERSHIP OPPORTUNITIES . . . . 908

III. A PRIVATE SECTOR ANALOGY FOR UNSOLICITED

BIDS: THE MARKET FOR CORPORATE CONTROL $\ldots \ldots 911$

IV. CENTRAL ISSUES IN THE ADOPTION OF A

PROCUREMENT PROCESS FOR UNSOLICITED

PROPOSALS FOR PUBLIC-PRIVATE PARTNERSHIPS . . . . 917

A. PROMOTING COMPETITION WITHOUT

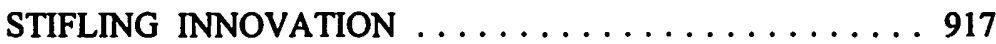

B. ENSURING TRANSPARENCY OF THE PROCESS ..... 918

C. POTENTIAL REACTIONS OF

INCUMBENT MANAGEMENT $\ldots \ldots \ldots \ldots \ldots \ldots \ldots 922$

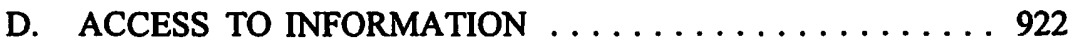

E. EVALUATING UNSOLICITED PROPOSALS ........ 924

V. THE PROPOSED PROCESS FOR UNSOLICITED BIDS . . . . 927

A. MODEL I: MODIFIED COMPETITIVE PROCESS . . . . 927

B. MODEL II: REQUEST FOR CONCEPTUAL

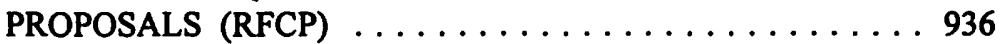

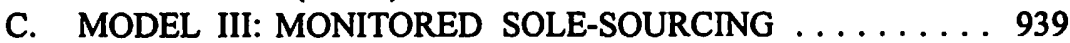

VI. CONCLUSION $\ldots \ldots \ldots \ldots \ldots \ldots \ldots \ldots \ldots \ldots \ldots \ldots \ldots \ldots$

\section{INTRODUCTION}

Governments are faced with fiscal pressures on many fronts. The economy must grow at a rate that can accommodate both a growing population and expectations of increased standards of living. In order to grow, not only must new infrastructure be constructed,' but the existing inventory of infrastructure must be replaced. Services ranging from defence to garbage disposal to the postal delivery system must be provided. These, vast maintenance, replacement, construction and service delivery expenditures must in turn be financed. It is clear that without innovative solutions it will become increasingly difficult for governments to maintain these expenditures. In order to facilitate economic growth and attempt to place resources in the hands of their most efficient users, governments of the 1990s have begun to inject competition into

$1 \quad$ World Bank Report, Infrastructure for Development (New York: Oxford University Press, 1994) [hereinafter World Bank Report]. See R. Daniels \& M. Trebilcock, "Private Provision of Public Infrastructure: An Organizational Analysis of the Next Privatization Frontier" (1996) 46 U.T.L.J. 375. 
the provision of infrastructure and services. ${ }^{2}$ More efficient provision of these vital components of economic well-being will ultimately allow government to reduce its leveraged position and thus utilize tax revenues for other purposes. ${ }^{3}$ This article will examine the manner in which the government can attempt to introduce private sector innovation into the provision of public goods and services, and will argue that by providing a process for the acceptance of unsolicited bids for government functions, efficiency goals can be more fully realized.

\section{CURRENT GOVERNMENT PROCUREMENT PRACTICES}

Government relations with the private sector can assume many forms, ranging from simple purchases of goods and services (contracting out) to outright sales of assets (privatization). This article focuses on a middle ground: partnerships between the public and private sector. The Federal Treasury Board Secretariat provides a working definition of partnering as

a collaborative arrangement between two or more parties based on mutual interest and a clear understanding, agreement or contract that sets out the objectives and terms of the arrangement. It is not a true legal partnership where the partners are liable for each other's actions. Partnering arrangements can be either formal or informal. ${ }^{\star}$

The distinguishing feature of public-private partnerships is their focus on encouraging innovative solutions to complex public sector needs. Private firms work with the public sector to develop new ways of delivering services and creating and maintaining infrastructure. It is the spirit of cooperative innovation that permits public and private sectors to work together and consequently enhance the efficiency of the delivery of government functions.

According to Kettl, ${ }^{5}$ the evidence on contracting out leads to the following conclusions:

2 “Only a Start on Trade Barriers" Financial Post (1 July 1994) 6. Federal Industry Minister John Manley estimated that the government procurement market alone (excluding Crown corporations) is worth about $\$ 50$ billion a year.

3 According to people like Indianapolis Mayor Stephen Goldsmith, as illustrated in W. Eggers \& J. O'Leary, Revolution at the Roots: Making Our Government Smaller, Better and Closer to Home (New York: The Free Press, 1995) the goal is not privatization but competition. Eggers and O'Leary explain that Goldsmith "claims he doesn't have a privatization program; he calls it a competition program." In short, he argues that the goal is not privatization for privatization's sake, rather any practice that will inject competition into government provision of goods and services should be entertained. See also H. Kitchen, Efficient Delivery of Local Government Services, Discussion Paper 93-15, Government and Competitiveness (Kingston: School of Policy Studies, Queen's University, 1993), in which Kitchen reiterates that efficiency is not necessarily related to whether the government or private industry provides a service, but rather is related to the degree of competition that exists.

4 Federal Treasury Board Secretariat, Framework for Alternative Service Delivery (Ottawa: 1995).

$5 \quad$ D.F. Kettl, Sharing Power: Public Governance and Private Markets (Washington, D.C.: Brookings Institution, 1993) at 157-65. 
- almost everything can be - and has been - contracted out

- almost everyone contracts out something

- $\quad$ everyone contracts out different things

- $\quad$ contracting out saves money

- competition is not always easy to develop or promote

- contracting out creates risks as well as advantages

In order to assess the desirability of implementing a process through which the government could entertain unsolicited proposals for public-private partnerships, the current procurement process must be understood. In general, in cases in which the government wishes to contract for the purchase of goods or services or completely divest itself of an asset, a tendering process is used. ${ }^{6}$ However, when the proposal involves a new project or a substantial development of, or change in, the undertaking being privatized in which "the Proponent's input into the design, technology, and construction, or expertise in management is sought ... [s] uch privatization will be conducted through a Request For Proposals." 7 Examples of major infrastructure projects that have been initiated through an RFP process range from Highway 407 in Toronto, to the Windsor Casino Project, to PEI's Confederation Bridge, to the Pearson International Airport redevelopment. ${ }^{8}$

\section{A. THE TENDERING PROCESS}

The tendering process is a procurement process that allows governments to award contracts based principally on price. 9 Once the government has identified a project in which some form of privatized arrangement is desired, a comprehensive set of technical specifications will be prepared. The government will consult with experts in an effort to craft a detailed proposal outlining its precise requirements and goals. The tendering process thus consists of the provision by the government of a document ${ }^{10}$ disclosing any terms or conditions that must be fulfilled such as deposit requirements, the timing of the transaction (and of the payments), the technological requirements, delivery conditions, inspection requirements and the representations and warranties to be given by the partner. "In short, the government spells out its specific desires and allows competing firms to bid for the project. The contract is awarded to the successful bidder on the basis of price if all of the other requirements are met.

For example, Air Canada and Teleglobe.

G.R. Baker, "Requests for Proposals and Tendering" (Address to Insight Conference, Toronto, 2223 November 1993) at 31 [unpublished].

See Daniels \& Trebilcock, supra note 1 at 375.

See Baker, supra note 7.

The document is referred to as an invitation to tender.

Selling to Government: A Guide to Government Procurement in Canada (Ottawa: Minister of Supply and Services, 1989) at 15 [hereinafter Selling to Government]. 


\section{B. THE REQUEST FOR PROPOSALS (RFP) AND REQUEST FOR QUALIFICATIONS (RFQ) ${ }^{12}$}

Unlike the invitation to tender, the Request For Proposals (RFP) is generally used by governments to initiate public-private ventures in cases where the government has not identified all of the specific features of the project. RFPs are used when projects have complex requirements thus prompting the government to attempt to tap the resources, expertise and innovativeness of the "bidding" companies. RFP projects are not generally awarded on price alone. Rather it is the "special capabilities or opportunities" of the potential supplier that determine the winner..$^{13}$

Projects can be initiated by multiple stages of RFP. Often, the procurement of unique projects begins with a Request For Qualifications (RFQ). The RFQ generally states the government entity's intention of providing private sector firms with the opportunity to engage in a specific public-private venture. The specific project is briefly outlined in an effort to allow prospective contractors to determine if their specific skills are relevant. This stage targets a wide array of companies and permits all interested parties to present their qualifications to the government. For example, the RFQ for Winnipeg's Charleswood Bridge project requested that the prospective bidders identify their general experience, the actual people who would be working on the project, their financial capacity (including financial statements of the proponent and its members), and references to verify all of the aforementioned information. ${ }^{14}$

The second stage of the procurement process is the initial Request For Proposals which is sent to those firms that meet the government's qualifications as identified in the RFQ. ${ }^{15}$ The RFP outlines the general principles and desires of the government with respect to the project. The specifications can range from being as general as requesting any proposal for a public-private initiative in transportation to a more specific proposal to perform a given function, construct a given structure or manage a given service. The government entity seeks project proposals that present a concept of the proposed project in clear and concise terms, including financial details, cost savings, reliability, and responses to environmental and legal concerns. The award of a project to the winning bidder is then often followed by detailed contract negotiations with that bidder, depending on how comprehensive the requirements are that are stipulated in the RFP.

For a general discussion see Canadian Council for Public-Private Partnerships, "Best Practice Guidelines: Initiating Contracts and Contracting with the Private Sector" (Toronto: June 1996).

Selling to Government, supra note 11 at 16.

The project consists of the construction of a twin span 4 lane bridge across the Assiniboine River requiring a proponent to deign, build, maintain and finance the bridge and repair the adjacent streets. See N. Bederman, F. DeLuca \& M. Trebilcock, Case Studies in Public Private Partnerships (Toronto: Canadian Council for Public-Private Partnerships, 1996).

It must be noted that the RFQ stage is often amalgamated into the RFP stage. In this case, the RFP is sent to companies that are known to the government entity, or is advertised in newspapers and journals. 


\section{SOLE-SOURCING}

An alternative model of procurement of government contracts that is infrequently used and controversial is known as sole-sourcing. A sole-sourced proposal consists of a project that is awarded to a single firm in the absence of competition. According to the official Guide to Government Procurement in Canada, sole-sourcing may be used in four distinct situations. ${ }^{16}$ First, it is permissible in cases in which the price of the good or service is established by statute or regulation. Second, if the requirement is a specific product for which substitutes are unavailable, incompatible, or would occasion loss of warranty, technical malfunctions or extreme maintenance costs, sole-sourcing may be used. Third, if the requirement is "urgent and any delay would be harmful to the public good," sole-sourcing may be implemented. Finally, when all pertinent factors and policies are considered, if there is only one firm that is qualified to fulfill the requirements, that firm can obtain a contract through sole-sourcing. The HamiltonWentworth/Philip Utilities waste-water management public-private partnership was solesourced, ostensibly falling under the fourth category. ${ }^{17}$ According to HamiltonWentworth officials, Philip Environmental was the only company that had a local headquarters, and that would guarantee to provide the region with additional economic development activities.

\section{CONSTRAINTS ON IDENTIFYING PUBLIC-PRIVATE PARTNERSHIP OPPORTUNITIES}

In order to reap the benefits of the private sector's technological, management and financial expertise, the government must identify a particular asset, good or service that it believes could benefit from private sector involvement. In identifying a potential target for a public-private partnership, the government is confronted with three types of constraints: information asymmetries, search costs, and bureaucratic and political incentives all of which hamper the government's ability to identify all potentially successful projects.

Informational constraints can hamper the government's ability to identify publicprivate partnership targets. The first of these is moral hazard, which refers to the limited ability of those charged with identifying potential projects to observe certain endogenous variables such as incumbent management's level of effort or intensity. While Laffont and Tirole apply this concept to the ability of government to regulate private firms, ${ }^{18}$ it seems to be equally applicable to procurement committees when such committees are composed of government officials who do not work directly in the selected target area. The inability to observe the endogenous behaviour of managers of

16 Selling to Government, supra note 11 at 15 . See generally Standard Acquisition Clauses and Conditions, Am. 97-1, s. 5 S.C. (Ottawa: Minister of Supply and Services Canada, 1991).

17 Hamilton-Wentworth and Philip Utilities Management Company (a wholly owned subsidiary of Philip Environmental Inc. of Hamilton) entered a public-private partnership in 1995 for the management of Hamilton's wastewater treatment facilities (see Bederman, DeLuca \& Trebilcock, supra note 14).

18 J.-J. Laffont \& J. Tirole, A Theory of Incentives in Procurement and Regulation (Cambridge, Mass.: MIT Press, 1993) at 1. 
potential public-private targets inhibits procurement officials from being able to detect inefficiencies, and thus limits their ability to identify potential candidates for partnerships. Moral hazard factors thus permit incumbent management to operate inefficiently without detection.

The second informational constraint that plagues procurement officials is what Laffont and Tirole refer to as "adverse selection."19 This constraint arises when the entity in question has more information than the regulator about some exogenous variables, such as the entity's actual technological capabilities and flexibility. Owen and Braeutigam explain how regulated firms employ tactics to create information asymmetries between themselves and the regulators. ${ }^{20}$ Similarly, by manipulating the flow of information to the procurement committee, a government entity can disguise its performance and reduce the chances of it being selected as a privatization target. Even without deliberate attempts to confuse issues, inconsistent internal accounting practices make the discovery of the actual costs of delivery of many services difficult to determine. For example, in order for Indianapolis Mayor Stephen Goldsmith to be able to assess the costs of delivering public services, he had to introduce "activity based costing" to create a uniform basis of evaluation. ${ }^{21}$ Without a uniform accounting practice that allocates costs to their appropriate sources, a procurement committee is unable to gain an accurate understanding of the actual costs of various services.

Search costs represent another form of constraint. Because of the plethora of government-provided services and activities, a thorough examination of each and an assessment of the merits of privatization would require considerable resources. Resources are simply not available to evaluate the merits of public-private partnerships for all government activities. Not only are there insufficient resources, those officials charged with identifying such possibilities are likely to be unaware of the complete range of abilities of the private sector and would thus be unable to determine what services could be provided more efficiently.

Even if the government could explore the merits of privatizing a large number of services, there are important measurement difficulties. The private sector will require that any activity that is performed must generate a positive profit. For every dollar of resources consumed, an efficient company will produce more than a dollar of output. While this calculus can be conducted in a straightforward manner by the use of profit and loss statements, "there is no similar tool to easily quantify the benefit of public activities. This difficulty in measurement, however, in no way excuses us from asking the tough questions: is this activity worth doing?"22 However, it makes the answer extremely difficult to determine.

Ibid.

20 B. Owen \& R. Braeutigam, The Regulation Game: Strategic Use of the Administrative Process (Cambridge, Mass: Ballinger, 1978) at 4.

lbid. at 28. 
"Public Choice Theory" applies the rational actor economic framework to collective decision making. ${ }^{23}$ The theory assumes that the economic actors in these political decisions, namely voters, politicians, bureaucrats and regulators, are motivated by selfinterest. According to Trebilcock, "economists have gradually come to recognize that the role of the state in a modern representative democracy is centrally concerned with mediating interest group conflicts over distributive claims." ${ }^{24}$ This observation leads to the suggestion that given limited resources, government procurement officials and their political overseers will search for those projects that would have the most beneficial political impact. Thus, principles of economic efficiency may not be the sole guiding factor. Instead, those projects that will appeal to interest groups and capture public favour will be examined before many less "glamorous" but perhaps more economically beneficial projects.

To date, governments have initiated the vast majority of public-private initiatives. Whether these relationships originate with RFPs and RFQs, tenders, or even solesourcing, the common component of such transactions is that they have been initially identified, at least in concept, by the public sector. ${ }^{25}$ By restricting public-private partnerships to those situations in which governments initiate the venture, the number and variety of such projects is dramatically reduced. First, as previously noted, the government is constrained by information asymmetries, search costs, and bureaucratic and political incentives. In addition, the government is unaware of all of the capabilities of the private sector, and thus even if it were not plagued by these impediments, it would be unable to identify all of the areas in which private sector expertise could enhance the efficiency of the provision of services or the construction and management of assets.

As evidenced by their infrequent use, unsolicited bids are beset by economic, political and legal concerns. Currently, governments do not have the benefit of a defined procedure through which they can reap the benefits of unsolicited proposals and simultaneously guarantee that the proposals will both enhance efficiency and be acceptable to taxpayers and private sector firms. In order to design an appropriate model for unsolicited bids in the government sector, an understanding of these legal, political and economic issues is essential. This article, through a review of academic literature, empirical evidence and personal interviews, will attempt to examine these issues and develop concrete proposals for an efficient model for unsolicited

See D. Mueller, Public Choice II (New York: Cambridge University Press, 1989).

M. Trebilcock, The Prospects for Reinventing Government (Toronto: C.D. Howe Institute, 1994) at 27.

While many proposals contain detailed descriptions of the government's desires, several proposals have been extremely broad. For example, in 1989 Caltrans, a government transportation authority in California, presented an RFP for four transportation-related development projects (this was authorized by the passage of Bill 680). Similarly, in Washington State (1994), the passage of statute RCW 47.46 (SHB 1006) which created the Public-Private Initiative in Transportation program, permitted the use of broadly worded RFPs to engage private companies in transportation development. The application of this style of RFP will be discussed in detail in Part V of this article. 
procurement of public-private partnerships for the provision of services and the development and maintenance of public infrastructure.

\section{A PRIVATE SECTOR ANALOGY FOR UNSOLICITED BIDS: THE MARKET FOR CORPORATE CONTROL}

The role of unsolicited bids for government assets and services can be illustrated by way of an analogy between unsolicited bids and the market for corporate control of publicly-traded companies. In order to understand this analogy, the economic and legal underpinnings of the market for corporate control must be understood. By examining the rationales and regulations that underlie takeovers of publicly-traded companies in the private sector, the desirability of an unsolicited proposal procedure for public sector functions can be assessed, and the most efficient procurement process for unsolicited bids can be illuminated.

The theoretical desirability of control transactions stems from an efficiency argument. ${ }^{26}$ Efficiency can be defined as the state in which resources are held by those who value them most highly. An efficient transaction is one in which resources are moved to a higher valued use. Inefficiency, therefore, does not simply exist in the case of greedy or lackadaisical management, but can exist where a firm's assets, through no fault of incumbent management, have the potential to be utilized with greater financial or organizational expertise by another firm.

Thus, the sale of a controlling interest in a given corporation will be attractive in two types of generic situations. First, a prospective purchaser may believe that the corporation in question can be managed in a more efficient manner and will thus generate more profit. ${ }^{27}$ Whether this state exists because corporate management has made a practice of indulging in excessive perquisites, or because management has simply become complacent with the status quo, a prospective bidder could purchase control of the company and alter its management. Second, the prospective purchaser may be able to employ synergistic practices to realize economies of scale or scope, and thus lower the operating costs or increase the revenues of the corporation. While incumbent management may be without fault, the specific circumstances of the prospective purchaser may permit it to conduct the target business more efficiently. In this case, the resources would be placed in the hands of a higher valued user, thus creating a Pareto superior improvement. ${ }^{28}$ In both cases, existing management is not

See generally, E.S. Herman \& L. Lowenstein, "The Efficiency Effects of Hostile Takeovers" in J. Coffee, Jr., L. Lowenstein \& S. Rose-Ackerman, eds., Knights, Raiders \& Targets: The Impact of the Hostile Takeover (New York: Oxford University Press, 1988) 211. can be installed.

A Pareto superior outcome occurs in a situation in which a transfer of control would make at least one party better off without making any parties worse off. In a corporate control transaction, this would imply that the incumbent management would be able to find equally productive work elsewhere, and the shareholders would receive a premium on the value of their shares. An argument may be made that a corporate control transaction may only be net efficiency enhancing and not Pareto improving. If the transfer increased net economic welfare, but did so at the expense 
operating the firm in the most efficient manner, and the prospective acquirer may be able to utilize the firm's resources more efficiently.

The purchaser's ceiling price ${ }^{29}$ will be the present value of the future income stream generated by the firm under new management. The existing owners' floor price will be the present value of the future income stream of the firm as it is currently being operated. ${ }^{30}$ The transfer of control, if it takes place at all, will take place at some price in between the buyer's ceiling and the seller's floor. Assuming that the projected management modifications are realistically designed, the buyer will be better off, as the acquisition will have taken place at a price which yields a positive net present value to the acquiring firm. By the same logic, the seller will receive compensation that is at least equivalent to the value of his current ownership stake in the target company. Thus, a transfer of ownership will not make either party worse off, and will ensure that the assets of the target company will be employed by a higher valued user. The social maximization problem, however, is ensuring that the assets end up in the hands of the most valued user. It is here that corporate law has attempted to safeguard shareholders and regulate the transfer of control.

\section{According to Michael Jensen,}

[o]ne major cause of takeover activity [is] the agency costs associated with conflicts between managers and shareholders.... Managers are the agents of shareholders, and because both parties are selfinterested, there are serious conflicts between them over the choice of the best corporate strategy. Agency costs are the total costs that arise in such arrangements.... When these costs are large, the threat or actuality of takeovers can reduce them. ${ }^{31}$

Public corporations which have widely held stock can be seen as composed of two entities. Managers are responsible for the day-to-day operations of the corporation, and shareholders are, in theory, responsible for the regulation and monitoring of management. If management is not operating in a manner that is consistent with the interests of the shareholders, the shareholders have the right to vote out incumbent management and install new managers. Many of the inefficiencies inherent in corporate management stem from the separation of ownership and management in the modern widely-held corporation. In short, the interests of managers and shareholders are often not aligned. Thus, each component of the corporation has different incentives and may be desirous of pursuing different corporate strategies. "The general problem of motivating one person or organization to act on behalf of another is known among

of decreasing the welfare of certain participants (i.e. employees), the situation may be beneficial in an aggregate sense (Kaldor-Hicks efficient), but would not be a Pareto improvement.

29 The price above which the purchaser will not consummate the purchase.

30 For publicly traded companies, the current stock price is a theoretical proxy for the present value of the future stream of income that will be generated by a company.

31 M.C. Jensen, "Takeovers: Their Causes and Consequences" (1988) 2 J. Econ. Perspectives 21 at 28. 
economists as the principal-agent problem." ${ }^{32}$ This separation of ownership and control led scholars like Berle and Means to articulate concerns over the accountability of corporate managers. ${ }^{33}$

At the core of the theory of corporate control transactions is the desire to ensure the closer alignment of the interests of managers with the interests of shareholders. The market for corporate control serves as an internal monitoring system for inefficient management. $^{34}$ By allowing firms to takeover other firms that are operating inefficiently and to realize a profit from the revised management strategy, the market for corporate control creates incentives for outsiders to monitor other firms. Attracted by the profit that can potentially be derived from purchasing another company with poor capital structure, inefficient management or other maladies, corporations become watchdogs for inefficiencies. In fact, it can be argued that "[ $[$ the process of monitoring by outsiders poses a continuous threat of takeover if performance lags" 35 and thus the mere presence of the threat of takeovers provides an incentive for incumbent management to serve shareholder goals. The fear of being displaced helps align management's interests with those of shareholders. ${ }^{36}$ For example, in the event of low stock prices, shareholders will be dissatisfied with corporate performance, and the firm may become a takeover target, thus exposing managers to the risk of displacement. By aligning the incentives of shareholders and managers, "the prospect of debilitating agency conflicts is minimized because the costs of opportunistic behaviour are reflected back onto the party engaging in such behaviour."37

The market for corporate control is not rendered redundant by the ability of individual shareholders to vote. ${ }^{38}$ The ability of shareholder voting to constrain agency costs is related to the magnitude and quality of information that is available to shareholders. The more aware shareholders are of management's practices and decisions, the better able they are to ensure efficient operation of the corporation. While information is obviously valuable, it can only be acquired at a significant cost. If shareholders could function as a single entity, it would be rational to assume that

P. Milgram \& J. Roberts, Economics, Organization and Management (Englewood Cliffs, N.J.: Prentice-Hall, 1992) at 214 [emphasis in original]. See also M.C. Jensen \& W. H. Meckling, "Theory of the Firm: Managerial Behavior, Agency Costs and Ownership Structure" (1976) $3 \mathrm{~J}$. Fin. Econ. 305; E.F. Fama, "Agency Problems and the Theory of the Firm" (1980) 88 J. Pol. Econ. 288.

A.A. Berle \& G.C. Means, The Modern Corporation and Private Property (New York: Macmillan, 1932).

J.S. Ziegel et al., Cases and Materials on Partnerships and Canadian Business Corporations (Toronto: Carswell, 1994) at 392.

3s F.H. Easterbrook \& D.R. Fischel, “The Proper Role of a Target's Management in Responding to a Tender Offer" (1981) 94 Harv. L. Rev. 1161 at 1174.

36 F.H. Easterbrook \& D.R. Fischel, The Economic Structure of Corporate Law (Cambridge: Harvard University Press, 1991) at 112-14.

$37 \quad$ Ziegel et al., supra note 34 at 391.

38 The presence of the phenomenon entitled the "Wall Street Rule" is important to note. There is empirical evidence that demonstrates that voters in widely held corporations have a tendency to respond to ineffective management by selling shares as opposed to voting. Obviously, this will further reduce the potential for shareholders to control agency costs. 
information would be gathered and processed up to the point at which the marginal benefit of obtaining further information equalled the marginal cost of obtaining it. However, information is a public good. ${ }^{39}$ Rationally, the individual shareholder will decide that since he cannot be prevented from gaining access to this information once produced, he would be better off "free-riding," and allowing others to produce it (often referred to as a collective action problem). Obviously, this rationalization when applied to all shareholders leads to insufficient information gathering. Thus, when shares in a corporation are widely held, shareholders suffer from what Robert Clark has referred to as "rational apathy." 40 In other words, although individual shareholders possess the right to vote, they do not have sufficient incentive to overcome the costs of gathering sufficient information to vote on important issues. As such, simply having the right to vote may be insufficient to curb the agency costs inherent in a corporation with separate management and ownership.

Besides the reduction of the principal-agent problems, another efficiency argument in favour of takeovers is the realization of synergy gains. Synergy can be observed in many forms; e.g. operating synergy (economies of scale or scope), or financial synergy (reduction in bankruptcy risk, reduction in cost of capital from increased internal financing). ${ }^{41}$ By acquiring control of another company, not only are scale and scope effects created, but "experience effects" arise. ${ }^{42}$ By combining an existing firm with a firm that has experience in the target firm's area of business, learning curve effects can be exploited.

Another motivation that can sometimes initiate a takeover bid is the potential for looting. Looting refers to purchases (or other transfers) of corporate assets from the corporation for insufficient consideration. The problem with these types of transactions is the differing benefits that may accrue to different parties within the firm. For example, while the under-priced sale of an asset may detract from the share value of the selling firm (and hence reduce share price, and thus reduce shareholders' net wealth), the incumbent management may be induced through financial benefits to cooperate with others. If looters could be detected ex ante, this sort of transaction could be easily eliminated. However, because prior scrutiny is impractical, courts have chosen to proscribe looting through less costly policies of deterrence. ${ }^{43}$ When caught, looters may be fined or imprisoned or made civilly liable. Courts have effectively increased the costs of looting while minimizing the costs of preventing or deterring looting. ${ }^{44}$

39 Ziegel et al., supra note 34 at 394.

$40 \quad$ R. Clark, "Vote Buying and Corporate Law" (1979) 29 Case W. Res. L. Rev. 776 at 779.

4 See R. Romano, “A Guide to Takeovers: Theory, Evidence and Regulation" (1992) 9 Yale J. Reg. 119 at 126-28; and generally J.F. Weston, K.S. Chung \& S.E. Hoag, Mergers, Restructuring, and Corporate Control (Englewood Cliffs, N.J.: Prentice-Hall, 1990).

42 "Cost Dynamics: Scale and Experience Effects" in D.F. Abell \& J.S. Hammond, eds., Strategic Market Planning: Problems and Analytical Approaches (Englewood Cliffs, N.J.: Prentice Hall, 1979). Monitoring would require considerable investigative resources, in the form of both time and money. 
Despite the economic efficiency advantages of a market for corporate control, governments and courts have adopted specific regulations with respect to corporate control transactions. A takeover is initiated by a bid ${ }^{45}$ to the target shareholders for some or all of the outstanding stock at a price generally greater than the market price of the stock. The premium above existing stock prices arises from the net present value of the enhanced efficiency that the acquiring firm believes that it can realize should its takeover bid be successful.

One main regulatory principle implemented in both the United States and Canada is that a corporation may not accumulate a block of shares large enough to achieve corporate control without disclosure. A purchaser in Ontario, for example, of 10 percent of the shares of a given corporation must file a press release and file a report with the Ontario Securities Commission (OSC) within two days of the purchase. ${ }^{46}$ Each additional purchase of 2 percent triggers a fresh press release and filing requirement. ${ }^{47}$ In the U.S., notification of the Securities and Exchange Commission (SEC) must take place upon reaching the 5 percent level. ${ }^{48}$ Public disclosure alerts the market that a potential takeover may occur. This enables both existing and potential shareholders in the acquired and acquiring corporations to adjust their investment strategies accordingly. It also allows incumbent management time to take actions designed to thwart the potential takeover. Management can either improve its operating efficiency and thus make itself a less attractive target or it can implement a defence and thus impede the takeover process.

Another key principle of the law of transfers of corporate control is that a bid for a corporation's stock must be held open for a minimum period of time. In Ontario, the minimum time is twenty-one days from the date of the bid. ${ }^{49}$ In the United States, the Williams Act requires that tender offers remain open for approximately one month. ${ }^{50}$ This rule permits other firms to enter higher bids, reducing the ability of any given firm to induce shareholders into accepting a low offer for fear that the offer will be withdrawn. ${ }^{51}$ An auction ensues when management resists the initial bid and

Ontario Securities Act, R.S.O. 1990, c. S.5, s. 89(1) defines "takeover bid" as "an offer to acquire outstanding voting or equity securities of a class ... where the securities subject to the offer to acquire, together with the offeror's securities, constitute in the aggregate 20 percent or more of the outstanding securities of that class of securities."

Ibid., s. 101.

In Ontario, there is an important exception. Like other provincial legislation, the Ontario Securities Act, ibid., s. 93(1)(c) permits a private purchase of control from five or fewer persons, provided that it occurs at a premium of no more than 115 percent of market price. In this situation, the purchase is not deemed a "takeover-bid" and as such is exempt from the legislation. If no exemption applies, the securities legislation applies and the offer must be extended to all shareholders. Because control in many Canadian companies is not widely dispersed, this exemption is an important component of securities regulation. See R.J. Daniels \& J.G. Macintosh, "Toward a Distinctive Canadian Corporate Law Regime" (1992) 29 Osgoode Hall L.J. 863.

Securities Exchange Act of 1934,15 U.S.C., c. $2 B, \$ \$ 78 \mathrm{~m}(\mathrm{~d})$.

Ontario Securities Act, supra note 45, s. 95(2).

Securities Exchange Act of 1934, supra note 48, c. 2B, $\$ \$ 78 n(d)-(f)$.

Bids that are held open for a very short period of time are referred to as "Saturday Night Specials." By eliminating the possibility of auctions, many believe that these bids are in fact harmful to shareholders, as they are not permitted to benefit from competition for control. 
successfully interests other companies in submitting subsequent bids. By forcing firms taking large positions in other firms to disclose immediately, and by forcing the bid to remain open, existing Canadian and U.S. laws both facilitate the creation of auctions.

There has been considerable debate as to the merits of Saturday Night Special takeover offers versus the prolonged auctions that are currently prevalent. The traditional case for auctions rests on the fundamental premises that auctions do not reduce the search for mismanaged companies below appropriate or efficient levels and help move target assets to their highest valuing users by injecting competition into the acquisition process. ${ }^{52}$ However, others argue that auctions in fact lower the potential gains from transfers of corporate control by encouraging bidding and thus reduce the incentive to search for targets in the first place by allowing subsequent bidders to free ride on search investments by initial bidders. ${ }^{53}$

There has also been considerable debate as to whether corporate management should play an active or passive role in response to a takeover bid..$^{54}$ Easterbrook and Fischel argue that "current legal rules allowing the target's management to engage in defensive tactics in response to a tender offer decrease shareholders' welfare.... Even where resistance leads to a higher price paid for the firm's shares, however, shareholders as a whole do not necessarily benefit." "W5 While it is possible that defensive tactics (e.g. "poison pills," "golden parachutes," "white knights") merely serve to stall bids and thus induce additional bidders, enhance competitive forces and thus elevate the takeover bid, if the company adopts a policy of stubborn resistance and succeeds in fending off all takeover bids, the shareholders lose whatever premium over market value the bidder offered or would have offered. Even the threat of defensive tactics can deter bidders and thus reduce shareholder wealth. ${ }^{56}$

The model of corporate control is analogous in many ways to the operation of government assets and services. First, the structure of a widely held corporation is similar in nature to that of the government. Government is like an almost infinitely widely held company - the limiting case of the Berle and Means corporation. Each citizen (over the age of eighteen) has a proportional "ownership" stake in the "performance" of government services and assets. Whether at the municipal, provincial or federal level, citizens have the right to elect their governing bodies which in turn operate the assets and deliver the services. Because of the separation of ownership and management, government officials have incentives that differ from those of the actual "owners" of the government. Thus, politicians and bureaucrats may often make

See for example L.A. Bebchuck, "The Case for Facilitating Competing Tender Offers: A Last (?) Reply" (1986) 2 J. of L. Econ. \& Org. 253 at 255-56. See for example A. Schwartz, "Search Theory and the Tender Offer Auction" (1986) $2 \mathrm{~J}$. of L. Econ. and Org. 229 at 239.

It can be argued that the mere threat of defences (as long as the threat is credible) can have an adverse effect on stock price. Because stock price is composed of a combination of the value of the current operations of the company as well as its potential sale value, eliminating the possibility of a takeover (which reduces the latter component) thus reduces the stock price. 
operational decisions that serve their own best interests. As previously discussed, the alignment of incentives between management and shareholders is a major rationale for the existence of the market for corporate control. This market serves as a check on management by providing a credible threat of displacing management that acts inefficiently (in its own self-interest). By drawing on the principles of the market for corporate control, we argue that the possibility of unsolicited bids will help align the incentives of the managers of government assets and services and the "owners" of those assets and services. The mere threat of displacement may be enough to force radical rethinking of internal management processes, as incumbent management and employees seek to retain their jobs. Unsolicited bids, much like hostile takeovers, force management to focus on efficient operation or be displaced by those who place a higher value on those productive assets. If unsolicited bids are facilitated, competition for innovative solutions would be injected into the public sector and taxpayers would benefit from more efficient operation of assets and services. It is important, however, to ensure that the process through which these proposals are submitted and selected is fair, transparent and efficiency enhancing. The following sections examine the issues surrounding the adoption of a regime in which unsolicited proposals may be entertained, and the methods by which this can best be achieved.

\section{CENTRAL ISSUES IN THE ADOPTION OF A PROCUREMENT PROCESS FOR UNSOLICITED PROPOSALS FOR PUBLIC-PRIVATE PARTNERSHIPS}

I will be inviting all Ontarians to provide the Government with their suggestions as to those government services that should be considered for possible privatization. The means for providing these suggestions will be announced shortly. 57

Obviously, the time is ripe to understand the implications of new ways of forging relations between the public and private sectors. As demonstrated in the previous section of this article, unsolicited proposals are an important way in which many of the objectives of privatization can be realized, permitting a more efficient provision of government functions. However, in order to understand how best to take advantage of unsolicited proposals for public-private partnerships, the essential issues surrounding this novel mode of procurement must be thoroughly understood. This section attempts to identify and address explicitly the most important of these issues.

\section{A. PROMOTING COMPETITION WITHOUT STIFLING INNOVATION}

Numerous authors have debated the economic efficiency merits of competitive auctions and tender bids in the market for corporate control. In the case of government assets and services that are the potential targets of public-private partnerships, a similar problem arises. Currently, most governments adhere to the policy of tendering almost all of the public-private ventures in which they engage whether they are simple supply contracts or complex partnerships. In the context of unsolicited bids, however, this creates a significant problem that is directly parallel to the hostile takeover situation. 
In the case of unsolicited bids, merely revealing the proposed target discloses some information that the innovator has used resources (be they financial capital or human capital) to ascertain. Hence, a conundrum is created: how can the government ensure political support through a competitive process, while at the same time safeguard the incentive to innovate by respecting the proprietary information contained in the innovative unsolicited bid? This problem pervades the unsolicited bid concept.

Private sector firms wish to safeguard their proprietary technology or innovative ideas and at the same time minimize the cost of submitting an unsolicited proposal. Private sector firms argue that even the act of revealing the object of the proposal can be detrimental, as it allows other private sector members instantly to acquire the innovator's proprietary technology. For this reason, many entrepreneurs will only reveal their innovative ideas to government if they are able to secure confidentiality agreements. ${ }^{58}$ Since governments are often reluctant or unable to enter such binding contracts, many potentially efficiency enhancing ideas are never shared with government. Private sector actors argue that, "[g]overnments have yet to establish a fair way of compensating people for their great ideas, and until they do, the private sector will have no desire to make unsolicited proposals." 59 Some RFPs state that all information submitted becomes the property of the government agency. "They want to own your proprietary right and your information, ... [t]hat shows a total disregard for the value of what you're doing, never mind how much you're spending to do it."160 Thus, the problem of providing incentives to create innovative concepts and share them with the government is in tension with the government's desire for a competitive procurement process.

Unsolicited bids enhance the level of mistrust. Government officials recognize that "unsolicited bids can open the door to corruption. In politics, even the perception of corruption is enough to cause serious problems. Neither government nor private companies want to be seen as corrupt." benefits from unsolicited bids, as well as to ensure public support, transparent procurement processes are needed.

\section{B. ENSURING TRANSPARENCY OF THE PROCESS}

In order to encourage the submission of innovative ideas, the adoption of a clearly stipulated and transparent process is essential. For example, the GATT Agreement on Government Procurement, while not dealing directly with unsolicited bids, states that,

[u]pon request by an unsuccessful tenderer, the purchasing entity shall promptly provide that tenderer with pertinent information concerning the reasons why the tender was not selected, including information on the characteristics and the relative advantages of the tender selected. ${ }^{62}$

Interview with Dan Taylor, Industrial Designer (9 July 1996). Interview with Bob Carman, Vice President, Government Policy Consultants $(9$ July 1996). Interview with Bill Longden, Vice President, Marshall, Macklin, Monaghan ( 9 July 1996). Interview with Shaun Hewitt, Metro Toronto Treasury (8 July 1996).

GATT Agreement on Government Procurement, 1 January 1981, Can. T.S. 1981 No. 39, art. VI, s. 3. 
Without the ability to assess the government's evaluation of their proposals, private sector innovators feel insecure about the fairness with which those proposals are evaluated. In the case of unsolicited bids, the government should make its general evaluation criteria public. ${ }^{63}$ By communicating the method of evaluation as well as the evaluation criteria, the public sector would provide a clearer indication of how it intends to deal with unsolicited bids.

In order for an unsolicited proposal to be evaluated and ultimately implemented or rejected, it must obviously be examined by people with appropriate skills. Currently, at no level of Canadian government is there an official receiver or repository for these documents. This raises the question of the merits of having a designated committee at each level of government, responsible for conducting a preliminary evaluation of all unsolicited proposals and keeping track of those proposals that may be of use in the future.

At present, unsolicited bids are submitted to a wide range of personnel. Bids are sent to both bureaucrats and politicians: they are sent directly to heads of departments, to senior financial officers, to commissioners, to elected representatives, to chief administrative officers, to officers of management boards, to public works and Supply and Services Canada, and to countless municipal city halls. In short, private sector constituents are not sure where to send their proposals. Because no defined channel exists, submissions are sent to those officials with whom companies have had previous relations or to those officials who companies believe would view these proposals favourably. This method of unsolicited proposal submission presents several problems.

First, the greater the number of people who are asked to perform initial evaluations, the greater the disparity in evaluation methods and criteria. Bureaucrats and politicians have differing interests and abilities. Often officials have strong opinions about privatization efforts. Some public sector employees recognize the potential benefits of public-private partnerships, while others are reluctant to embrace the concept. Some proposals cannot be properly evaluated in the absence of financial, legal or engineering expertise, yet they are often initially evaluated (and potentially dismissed) by officials lacking appropriate skills or time. ${ }^{64}$ In effect, each bureaucrat who is presented with an unsolicited proposal has an "implicit veto." While this "veto" can be employed to eliminate frivolous proposals, it can also be used to protect the vested interests of bureaucrats or agencies.

Second, the problem of lobbying has to be addressed. Because there is no defined channel through which proposals must be sent, unsolicited bidders are free to target and consequently lobby any official in any branch of any department of government. Conflicting views characterize the lobbying problem. Private sector members argue that because lobbying advantages those established companies with close ties to public officials, newer and often smaller companies are put at an unfair disadvantage and may in turn begin to distrust the system and be wary of submitting bids in the future. The 
significance of this problem becomes evident if one considers that many innovative ideas tend to come from newer, smaller companies. Hence, by permitting lobbying to continue to dominate the selection process, governments may in fact be decreasing the number and quality of innovative solutions available to them. By eliminating or reducing the effect of lobbying on the unsolicited bid process (e.g. by adopting antilobbying prohibitions disqualifying RFQ/RFP participants who attempt to make contact with government officials other than the officials responsible for conducting the process), the playing field would be levelled. Not only would newer, innovative companies be given more access, but confidence would be increased that decisions are based strictly on the merits of given proposals and are not the product of patronage or corruption.

By constituting a centralized initial evaluation committee that has no vested interest in any given department, the incentive and ability to implement an "implicit veto" is removed. In addition, by reducing lobbying and providing a defined channel for procurement, a central committee would restore credibility and comprehension to a murky process, inducing more private sector innovators to submit proposals.

In order to minimize the cost of this committee, its responsibilities should be limited. This body should act as a preliminary screening mechanism that is responsible for providing political representatives or decision-makers with sufficient information to decide whether privatization in general is acceptable, and second as a final evaluator of competing proposals. It must consequently have the authority to draw upon the resources (including people situated within the particular government department that is the target of the proposal) necessary to evaluate the proposals as well as access to the politicians who will be responsible for the initial privatization decision. The proposals should be evaluated on a preliminary basis to determine whether or not they are financially, operationally and legally feasible and economically and politically desirable. The committee should prepare a brief written evaluation in order to provide the political decision-makers with appropriate information and recommendations to make decisions regarding the desirability in principle of a public-private partnership in a particular context. If political representatives approve the concept of a public-private partnership in a given context, the committee should also have the authority to appoint a final evaluation sub-committee that would be responsible for making the final selection between proposals (should more than one be submitted). This would permit politicians to make decisions regarding general policy priorities, but would vest in qualified financial, technical and legal experts decisions regarding the precise application of these policies by removing politics from the selection process, thus enhancing the credibility of the evaluation process. Additionally, the committee should be responsible for keeping a $\log$ of the proposals it receives. Because some proposals may contain desirable ideas that are simply not feasible in the current context, the proposals could be kept on file and reopened should the context change. ${ }^{65}$ Finally, the committee should be responsible for issuing a document at the completion of the entire evaluation process that explicitly outlines the evaluation process used, the evaluation criteria employed and a summary of the reasons why the winning proposal was selected and why others were not. 
Assuming that a centralized committee would reduce the "implicit veto" problem and lend credibility to the procurement process, government must decide under whose auspices the committee will reside. The problem, generic to all three levels of government, is whether or not this committee should be a part of an existing division of government such as Supply and Services Canada or the Management Board Secretariat of the Ontario government or whether it should exist on its own. Ontario's most recent budget identified the imminent creation of a privatization committee. ${ }^{66}$ This committee could house an evaluation body for unsolicited proposals, and a similar structure could be developed municipally and federally. Alternatively, by creating the committee under the auspices of, for example, Management Board of Cabinet, an organization that has been in existence for almost forty years, concerns over the robustness of the organization may be reduced. The Management Board already has responsibility for orchestrating improvements in government and would thus be a logical repository for unsolicited proposals in Ontario. ${ }^{67}$

Because the evaluation will require legal, financial and engineering expertise, the committee should contain at least one lawyer, one financial analyst, and one engineer. These people should ideally have experience working in both the public and private sectors, or at any rate should be drawn from both sectors, so that they will have some familiarity with both the political and economic implications of proposals received. It is important to recognize that both the initial evaluation (which will provide political representatives with sufficient information to decide whether any privatization in principle should occur), as well as the final evaluation, will often require the expertise of government employees who have direct experience with the department that the proposal is targeting. As a result, the initial evaluation should be conducted on a teamlike basis, in which the permanent members of the committee solicit the help of specific public sector employees (engineers, managers, operators, etc.) and private sector experts in order to obtain the most accurate understanding of the potential for a proposed public-private partnership.

The committee should restrict the tenure of any member to between three and five years. The reason for this is twofold. First, members of the committee should not be permitted to submit unsolicited bids. Because it is desirable that these members have some private sector experience, it is possible that by serving on the committee, they will be prejudicing their own livelihood. Hence, by instituting maximum tenure, private sector members will not be prohibited from submitting unsolicited bids permanently. Second, like any organization, stagnation should be avoided. Because this is a dynamic area that depends on innovation, regular turnover of personnel may help maintain an innovative attitude.

While efficiency concerns both the public and private sectors, governments are accountable to the electorate, and government decisions will be based upon a social analysis that differs from the private sector calculus. It is essential that the private sector understand the complexity of the political decision-making process and the need

67 The federal equivalent may be Supply and Services Canada, and the municipal equivalent may be the Treasury or Financial Department. 
for governments to act in a manner that will engender public support; governments must at all times remain accountable to the electorate. However, in exchange for this level of understanding, the public sector must realize that it must explain how it arrives at its decisions and it must act accordingly. In short, it is incumbent upon government to publicly define the specific policy framework in which it acts, and then act consistently within that framework.

\section{POTENTIAL REACTIONS OF INCUMBENT MANAGEMENT}

In the private sector, incumbent management can take advantage of certain defences to hostile takeover bids in an effort to protect itself from being displaced. In the public sector, incumbent management of an asset or service may have a similar desire to safeguard its own existence. While public sector organizations are not publicly traded companies and can thus not implement tactics that are dependent on voting, such as poison pills, a form of white knight strategy can be implemented. Incumbent officials may attempt to leak news of an impending RFP to certain companies, and it may attempt to influence decision-makers and thus cause them to select an organization whose plan includes the retention of management and employees.

While the ex post options available to management of public services and assets are limited, there is one powerful ex ante tactic that can be employed to reduce the possibility of privatization. "Often government will not account for all of the costs associated with providing a service; therefore, on the surface the government agency looks cheaper than the amount proposed by the unsolicited proposal or bid." ${ }^{18}$ This can be done by adopting confusing accounting practices, by failing to allocate costs in the most explicit and informative manner or by refusing to recognize certain common costs in a proportionate manner. In order to ensure a "level playing field," these practices should be discouraged where possible. By having departments adopt activity based costing, a more accurate understanding of operational costs will result. ${ }^{69}$

On the other hand, there can be no objection to allowing incumbent management or employee groups to bid to retain existing functions (perhaps on different terms) in a competitive bidding process precipitated by an unsolicited bid, provided that all costs associated with retaining the function in-house in its present or restructured form are properly accounted for in the bid. Indeed, much empirical evidence suggests that the existence of competition, as much as the nature of ownership interests, determines the efficiency with which public functions are performed. ${ }^{70}$

\section{ACCESS TO INFORMATION}

While Access to Information statutes generally provide a mechanism through which private sector applicants can obtain all available information regarding the current

Activity Based Costing is an internal/managerial accounting practice that allocates overhead and other expenses in a manner that provides an accurate picture of the true costs of the business.

See J.D. Donahue, The Privatization Decision: Public Ends, Private Means (New York: Basic Books, 1989) at 82. 
operating performance of government managed assets and services, an important information problem still exists. ${ }^{71}$ While some functions generate comprehensive financial information, many government services and assets have not yet been examined in a private sector, financial analysis context. In addition, government activities are not required to adhere to Generally Accepted Accounting Principles, and thus may not have records that informatively reflect the operational performance of these functions. In short, insufficient operational and financial information about government functions is common. Thus, not only is the private sector unable to acquire complete information, but the public sector is unable properly to assess proposals regarding particular functions. Part of the benefit of a competitive bidding process is to educate the government about the approximate market value of a given asset or service. However, if only one bid (unsolicited) is made, the government has no comparative basis by which to establish the correct market value range. Hence, not only does the absence of regular financial evaluation make financial information difficult for the private sector evaluator to obtain, it also prevents the government from being able to assess adequately the appropriateness of a given unsolicited proposal. The Ontario government's Common Purpose Procurement Model stresses that the government should be assessing and valuing its services and assets in order to be in a better position to evaluate proposals from the private sector. ${ }^{72}$ However, it will take considerable time for the government to perform such analysis of all of its functions. In order to facilitate unsolicited bids, therefore, government functions should be subject to uniform accounting procedures (including activity-based costing).

Access to information also refers to the balance between the public's right to access government documents and commercial concerns over privacy. Once a proposal is sent to a government entity, it generally is considered to be the property of the government and as such falls under the purview of Freedom of Information Acts, and is thus susceptible to Freedom of Information Requests. This presents an obvious proprietary information problem. The Commonwealth of Virginia, in its Public-Private Transportation Act of 1995, which provides a policy framework for unsolicited proposals, includes the following section:

If a proposer has special concerns about proprietary information which it would desire to make available to VDOT, such proposer may wish to suggest for VDOT consideration, prior to submission of its proposal, methods for safeguarding such information from disclosure consistent with the Freedom of Information Act. ${ }^{73}$

In order to realize benefits from innovative unsolicited proposals, a mechanism through which the proprietary nature of information can be disclosed is essential. In the event that this is not provided for, proposers will either refuse to submit proposals, ${ }^{74}$

71

For a discussion of the operation of access to information legislation in this context, see $E$. Atwood \& M. Trebilcock, "Public Accountability in an Age of Contracting Out" (1996) 27 Cdn. Bus. L.J. 1.

Management Board Secretariat, Province of Ontario, "Ontario's Modified Common Purpose Procurement Format: A Guide for Information Industry Supplies" (Toronto: February 1996).

3 Commonwealth of Virginia, "Public-Private Transportation Act of 1995 Implementation Guidelines" (Richmond, Va., 1 July 1995) [hereinafter Virginia Implementation Guidelines]. Taylor, supra note 58. 
or develop unique (and potentially wasteful) methods of safeguarding their proprietary information. $^{75}$

One situation in which strict secrecy is clearly necessary arises when the innovator plans to transfer the innovative proposal to other municipalities, provinces, states and countries. Should a proposal be submitted in one jurisdiction and subsequently not be adopted, the proprietary nature of the information will permit the innovator to attempt to "sell" the proposal elsewhere. If the confidentiality of the proposals is not protected, the loss to the innovator may be greater than the failure to implement the idea in that jurisdiction. Often innovative financing or organizational proposals will depend on the incidence of implementation to generate profit for the private sector proposer. Hence, a loss of confidentiality, and thus a potential loss of revenue in other jurisdictions, may be sufficient to prevent the submission of the proposal in the first place. For this reason, innovators submitting unsolicited proposals will often omit important details from their proposals, thus ensuring confidentiality. The ensuing problem, of course, is that government receives incomplete proposals that cannot be properly evaluated or understood. Thus, the transferability of innovative concepts creates a case for exempting some portion of unsolicited proposals from Access to Information Acts.

\section{E. EVALUATING UNSOLICITED PROPOSALS}

Unlike traditional procurement, unsolicited proposals for public-private partnerships are the potential basis of long term relationships between the public and private sectors. In order to identify and maintain successful long term relationships, the major cultural differences between the two sectors must be understood. It is through these differences that private sector entrepreneurial firms will be able to provide efficiency gains through innovative, unsolicited proposals. By focusing on those qualities which bureaucracies do not possess, private sector firms can implement innovative solutions to public sector problems that have yet to be solved through traditional means. The following table identifies the major cultural differences between the sectors, and thus may illustrate how private sector firms can help the public sector. ${ }^{76}$

For example, one Metropolitan Toronto proposer obtained an office next door to the municipal building in which all of the information regarding the proposal was kept. In this manner, government officials could view the material without ever having possession of it, thus exempting themselves from the Access to Information Act. 
Table 1

ENTREPRENEURIAL CULTURES vs. BUREAUCRATIC CULTURES

\begin{tabular}{|c|c|}
\hline $\begin{array}{c}\text { Characteristics of } \\
\text { Entrepreneurial Cultures }\end{array}$ & $\begin{array}{l}\text { Characteristics of } \\
\text { Bureaucratic Cultures }\end{array}$ \\
\hline $\begin{array}{l}\text { Risk taking } \\
\text { Innovative } \\
\text { Quickly adaptable to change } \\
\text { Independent decision-making } \\
\text { Accepting of failure } \\
\text { Emphasis on operative advice } \\
\text { Emphasis placed on achieving a purpose } \\
\text { Emphasis on short term goals } \\
\text { Personal structure: few rules } \\
\text { Responsive to individual client and } \\
\text { customer needs } \\
\text { Focus exclusively on financial } \\
\text { considerations and efficiency } \\
\text { Efficiency-based decision-making process }\end{array}$ & 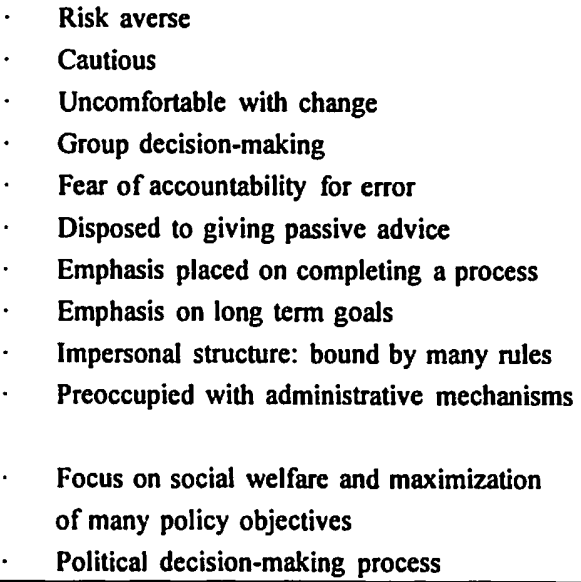 \\
\hline
\end{tabular}

In order properly to assemble an unsolicited bid, private sector entities must thoroughly understand the implications of these differences. By being aware of the government's commitments to multiple policy objectives as well as its political decision-making process, private sector firms will have more realistic expectations regarding the acceptance of unsolicited proposals, and will consequently be able to tailor those proposals in such a way as to facilitate their adoption.

In order to create incentives for private sector innovators to submit proposals, the public sector should identify and publicize a comprehensive list of evaluative criteria. Taking into account the differences between the public and private sectors, as well as the fact that partnerships will often involve more complex relations than simple purchase or sale contracts, evaluation of unsolicited proposals for public-private partnerships will necessarily involve more than a mere examination of price. The evaluation must ensure that the proposal will withstand public scrutiny, ensure customer service and provide the best value for the tax dollar. By identifying the evaluative criteria, the public sector accomplishes two goals. First, it provides the innovator with a guideline for assembling an unsolicited proposal. Second, it introduces an element of transparency in the evaluative process that will enhance the level of confidence that the private sector and the public at large have in government evaluations. It will reassure the proposer that a thorough assessment will be made, and that consistent treatment will be given to all such proposals. The following list identifies some of the criteria which are relevant in evaluating unsolicited proposals for public-private partnerships. ${ }^{77}$ Of course, the differences in nature and magnitude of various proposals necessitates a caseby-case judgment of the applicability of the following criteria. 
(a) Qualifications and Experience

- Experience with similar infrastructure projects

- Demonstration of ability to perform work

- Leadership structure (applicable if the proposal originates from a consortium or group of entities)

- Project manager's experience

- Management approach

- Financial condition of the proposer

- Project ownership: responsibilities of each partner in each phase of the proposed project

(b) Proposal Characteristics

- Project definition

- $\quad$ Proposed project schedule

- $\quad$ Performance strategy

- Technology

- Conformance with laws, regulations and standards

- Federal, Provincial and Municipal Permits

- Compliance with environmental standards

- Ongoing operations and maintenance

(c) Project Financing

- Financial/Business plan

- Financing ability

- $\quad$ Estimated cost to government

- Life cycle cost-benefit analysis

- Reasonableness of macro and microeconomic assumptions

- Financial Guarantees

- Insurance coverage

- Financial Risk Analysis

(d) Public Support

- Community benefits: direct or indirect benefits/costs

- Community support for the project

- Community perception of the firm: ability of the firm to work in the community

- Public involvement strategy: strategy for informing, educating and obtaining community input throughout the development and life of the project

- Political and Bureaucratic Risks 


\section{THE PROPOSED PROCESS FOR UNSOLICITED BIDS}

Discussions with members of both the public and private sector reveal that an important ingredient of the successful utilization of unsolicited bids is an articulated process. While the process need not be followed to the letter in each application, the provision of a generic procurement model will provide both the public sector and the private sector with invaluable information. Both sectors will have a prescribed path along which all unsolicited bids must travel in order for them to be accepted. Channels of evaluation will be defined and decisions made by people who are both qualified and empowered to do so.

The private sector will experience several major benefits. First, having an articulated process will help create an atmosphere of trust. Private sector members who submit initial unsolicited proposals will be aware, in advance, of the process which they must follow in order to enter into a successful unsolicited venture. An understanding of the various stages of evaluation may provide these innovators with a realistic view of what will occur, and will consequently account for what may otherwise appear to be unnecessary delays. In addition, the more defined and transparent the process, the less likely participants will be to claim that unfairness or preferential treatment has occurred. A well-defined process incorporating competition will reduce the potential for corrupt or biased procurement. Not only will innovators and bidders appreciate a defined process, but the taxpayer and utilizer who is the ultimate customer of the service will have greater faith in the integrity of unsolicited proposals.

Now that the major issues concerning unsolicited proposals have been reviewed, several potential unsolicited bid models will be identified. Each model will be examined in the context of these issues, because no single model can be identified as the ultimate solution to the challenges posed by unsolicited bids. Both public and private sector actors should consequently identify which model or combination of models is best suited to their particular situation.

\section{A. MODEL I: MODIFIED COMPETITIVE PROCESS ${ }^{78}$}

This model squarely addresses the main conundrum raised by unsolicited bids: how can governments ensure competitive procurement in order to ensure political support and accountability while at the same time sufficiently protect the proprietary rights of innovators to ensure that they will continue to offer innovative solutions to government problems. The "modified competitive process" is a multistage model in which an innovation is ultimately converted into an RFQ or an RFP, but special privileges are granted to the private sector entity responsible for the initial submission. A brief outline of the model follows. 


\section{The Process}

a. Innovator Submits Proposal

The process is initiated by an unsolicited submission from a member of the private sector. The initial proposal should contain:

- the specific asset or service that the innovator wishes to operate under a public-private partnership with the appropriate government entity,

- the general terms and conditions under which the partnership would exist,

- the relevant financial information including the proposed cost savings, etc.,

- a description of the proposing organization, its accomplishments and current ventures,

- references that will corroborate the innovator's accomplishments.

Currently, these types of unsolicited proposals are sent to all levels of government and all departments. However, as proposed above, the proposal should be sent to a centralized evaluative body that is designated as the only acceptable recipient of such unsolicited proposals.

One important consideration is the amount of information that must be included in this document and the corresponding treatment of the disclosed information by the government. Unless the proposer can secure some sort of confidentiality agreement from the public sector before submission, the initial proposal will be vulnerable to Access to Information Acts. Hence, there is a dilemma regarding the amount of information that should be included in the initial proposal. The private sector entity must provide sufficient information to create both interest and credibility. However, it will want to include as little information as possible in order to avoid loss of proprietary information. If, however, a mechanism exists that will provide the innovator with special safeguards or privileges, more complete proposals will be submitted. The knowledge that special protection will be granted may be sufficient to create an incentive to disclose sufficient information to permit proper initial analysis.

b. Review of Initial Proposal by Government Entity: Is the

Proposed Asset or Service a Desirable Public-Private Partnership Target?

As explained above, the initial evaluation should be undertaken by a centralized committee for the information of politicians responsible for making the relevant policy decisions. This evaluation will focus on the general acceptability of the innovative concept. It will address the question of whether the proposed function is one in which the government is prepared, in principle, to enter into partnership with a private sector entity. The initial evaluation committee should provide politicians with a general analysis of the potential implications of partnering in the context of the proposed asset or service, and not with the specifics of the particular proposal or proposer.

In the event that the proposal raises an issue of privatizing an asset or function that has yet to be considered by the government, a decision about the desirability of a 
public-private partnership has to be made. In order to provide politicians with sufficient information to determine whether the particular proposal would compromise public policy objectives, or raise public policy concerns, the evaluation committee must understand the current operations of the asset or service in question. In order to best evaluate the current operational and financial performance of the function, the committee should consult directly with officials responsible for the function who are aware of the intimate operational and financial details. The following outline, adapted from the World Bank, may serve as a guide in deciding whether to enter into relations with the private sector or to keep the operation of a government function entirely in public sector hands. ${ }^{79}$

\section{i. Determine the Nature of the Economic Environment in Which the Public Function Operates}

The World Bank model suggests that the first step should be an examination of the nature of the environment in which the asset or service operates. It may operate in a competitive, potentially competitive or naturally monopolistic environment. Privatization decisions will depend on which economic regime governs the function's market. The less competitive the environment, the greater the need for public regulation or involvement to protect the public from attempts by the operator to extract monopoly rents.

\section{ii. Assess the Risks Versus Rewards of Potential Private Management}

This decision is an extremely important element of unsolicited public-private partnerships. Perhaps the most significant cause of government reluctance to accept unsolicited proposals is the concern that "the benefit to government must be worth the political risk." ${ }^{80}$ The concept of risk is a difficult one to assess, because many different risks exist, and they are weighted differently depending on the circumstances. For example, the risk of failure to perform will depend greatly on the context. If a private sector partner fails to properly fulfill a parks maintenance arrangement, political risk may be relatively limited. However, the failure to properly manage air safety control could have devastating political implications. Thus, in the decision, the potential savings must be viewed in the context of the public importance of the function.

\section{iii. Assess the Current Operating Performance of the Function}

Once the social and political implications of the partnership in question are understood, the decision regarding public-private partnership will rest, in part, on an understanding of the current performance of the public function. Without an understanding of the current financial operations of the given function, an informed evaluation of unsolicited proposals cannot be made. Performance, however, must be examined in several different dimensions, ranging from financial performance to the

so Interview with Wendy Noble, Director of Corporate Policy Division, Government of Ontario (22 July 1996). 
success of the function in achieving its social and political objectives. If the function is deemed to be appropriate for public-private partnership, the government can then use these various measures to assess proposals. Hence, by examining the function, not only does the government inform itself of the merits of privatization of the function, but also provides numerical criteria from which benchmarks can be constructed and evaluations made.

\section{Financial Performance}

The first aspect of performance that should be examined is the function's financial performance. ${ }^{81}$ Because of the ambiguity of the definition of financial performance, the World Bank identifies two key ratios to examine. The first, operating surplus to sales in current prices, is a good indication of the function's return. This figure provides an indication of the ability of the function to generate revenue from the distribution of its good or service. If comparable private sector enterprises exist, a comparison should be made. If not, the trend should be analyzed and this should be compared to the expected operating surplus to sales under public-private partnership.

The second measure of financial performance, if applicable, is a measure of the before tax profits in current prices, which represents the government's return (if it were a private owner). This is an absolute measure, as the profit figure is not compared to the capital required to generate that profit, or the risk assumed by the government in the facilities' operations. Thus, gross profit is merely an indication of whether the function is a net contributor to government deficits or whether it is a net contributor to revenue. ${ }^{82}$

\section{Productivity}

Another important indicator of the performance of the public function is its productivity. Again the World Bank identifies two separate measures of productivity. First, the real variable unit costs (if applicable to the particular function) must be evaluated. Next, total factor productivity or the total quantity of outputs that are produced per input must be discovered. Once again, trends can be examined by noting that productivity increases when either total factor productivity increases or when real unit costs decrease. Hence, by examining the actual productivity of the function, the

While current financial performance is most important, trends in financial performance are a useful method of assessing the future direction of operations. Examinations should therefore look at the patterns in financial performance, in conjunction with major economic and political events. For example, if current profitability of a given service is low, one must discover whether this is correlated with the macroeconomic trends, whether it is an aberration from an otherwise good performance record, or whether there is a pronounced upward trend in the financial performance of the function.

There are several key problems with these criteria. It is important to understand that many public assets and services were designed for non-commercial goals like poverty reduction and job creation. Hence, in order to evaluate the true performance, the net benefits from these goals should be included in the calculus (based on some proxy for the relative success in achieving them). See World Bank Report, supra note 1 at 60 for arguments as to why this problem is not especially detrimental to the analysis. 
government can ascertain the minimum improvement that would have to be provided by prospective bidders.

\section{Savings Investment Deficit and Budgetary Constraints}

The savings investment deficit refers to the extent to which the function relies on external sources to finance its operations, expansion and debt service. A persistent deficit is bad for the budget, and may reflect poor management, operations and investment choices. Understanding government budgetary constraints will provide guidelines for the financial obligations that the public sector is willing to undertake in such partnerships, as well as the importance of the savings that these projects may generate.

\section{Social and Developmental Objectives}

Finally, an evaluation of the existing social and developmental commitments and objectives will permit a complete evaluation of the costs and benefits of partnerships. Because the proposal is unsolicited, the policy commitments may not have been previously explicitly identified. Therefore, an analysis of government social and developmental policies, and how well the existing function is achieving them, is essential to a decision regarding an unsolicited public-private partnership.

c. If Threshold Question is Answered Affirmatively,

Craft a Request for Proposals or a Request for Qualifications.

Once the decision has been made that the asset or service that was identified in the initial unsolicited bid is suitable for public-private partnership, the government can inject competition into the procurement process through either a Request For Proposals or a Request For Qualifications document. Considerable debate surrounds the choice between these two methods.

The belief that a competitive tendering process necessarily increases government benefits is widely held. Consequently, governments are generally predisposed to issuing RFPs. However, in order to implement a competitive tendering process, the private sector bidders must be aware of the tender target. In the case of unsolicited bids, the problem of proprietary information arises. The initial proposal may be the result of considerable innovation and resource expenditures and may consequently have significant proprietary value. However, in order to initiate a competitive tendering process, the government must, in some form, reveal at least a part of this proprietary knowledge. As a compromise, the government should adhere to the policy that is currently being implemented by some municipal governments in Ontario. Namely, instead of providing a precise description of the function that government is tendering, the RFP document should merely identify the problem that government has, and leave the particulars of the solution undefined. By merely outlining the problem, the government protects the proprietary interest of the innovation to an important extent (the actual target must still be identified), but firms are permitted to submit any innovative solutions that they may have. 
An additional problem with an RFP process is the potentially enormous cost of preparing (and evaluating) a bid. Instead of merely assembling a bid for a specified product (which can still be expensive) firms are asked to submit innovative bids. As a result, firms may be reluctant to undertake such large expenditures knowing that there are no contractual guarantees and there are no limits on the number of firms that may be able to submit bids and no guarantee that any contract at all will be awarded at the end of the process. Individual firms are discouraged from submitting proposals because of a combination of the cost and the large number of other firms that may submit proposals, each one lowering the probability of success. Despite the disincentive for individual firms to respond, the unrestricted nature of the RFP will still often result in a significant number of proposals being submitted. Consequently, the evaluation and administrative costs of the process will also be increased. The result may be a considerable waste of social resources.

Thus, instead of having many firms submit expensive innovative proposals in response to an RFP, the government should, once it receives an unsolicited proposal, issue a general Request for Qualifications document with respect to the general area identified by the unsolicited proposal. In this case firms would only have to submit relatively inexpensive information about themselves, and would be informed quickly about whether they qualify for the "short-list" of firms that would be invited to submit proposals for the project. The advantage of this method would be twofold. First, only a small number of qualified firms would have to undertake the expense of preparing innovative bids. Second, the evaluation process will be faster and less expensive for the government because there will be fewer proposals and all of the bidders will have already been approved and thus deemed able to carry out their proposals.

This RFP/RFQ stage of the process should be held open for a fixed period of time. If an RFQ is used to initiate the process, a short initial response period is justified, as qualifications can be prepared more easily and cheaply. When an RFP is used initially, however, more time should be provided, although too much time would be disadvantageous for both the public and private sectors. Private sector participants have an interest in having the process move forward as rapidly as possible. According to numerous sources, the longer the entire process takes, the less faith bidders have in it. As well, the longer the RFP is left open, the more bids will be submitted and hence the more difficult the evaluation process and the greater the social cost of losing bids. ${ }^{83}$ The government should also commit to evaluating responses to RFQs and RFPs within a fixed and relatively limited period of time.

It should be noted that the Prince Edward Island fixed link public-private partnership, a federally sponsored project to build a 13.5 kilometre bridge across the Northumberland Strait, was characterized by numerous bidders undertaking extremely expensive bids over a long period of time, driving several to bankruptcy. Because of public concern about the social impact of the project, it took over six years to move from the initial request for expressions of interest to a completed contract. In the process twelve bidders expressed initial interest and five eventually submitted bids in the final bidding stage. The winning bidder is reported to have spent \$30 million on the process up to the point of signing the contract. In the Highway 407 tollroad project north of Toronto, the final bidders are reported to have spent \$3-5 million each on the process. See generally Daniels \& Trebilcock, supra note 1 . 


\section{d. Final Evaluation and Selection}

If the RFP model (not RFQ) is selected, this stage will entail a final evaluation of all of the proposals and the selection of the best proposal. Because the desired outcome is a partnership, and the function has not previously been considered by the government (unsolicited), more criteria should be examined than merely price. While each case will entail certain obvious criteria, a comprehensive list from which to select is included in Part IV of this article. If the RFQ model is implemented, this allows the government to select a company with whom it would be comfortable entering into a partnership. Once several companies have been selected, proposals will be submitted and the best will be chosen.

Upon final selection of a proposal, the evaluation committee should prepare a brief document describing the winning bid, the selection criteria that were applied, the selection process that was followed and the major reasons that the winning proposal was selected over other proposals. In order to further ensure that the process was fair, an independent consultant with significant reputational capital at stake can be retained to certify that the evaluation was both comprehensive and impartial. This safeguard will pre-empt charges of favouritism and enhance confidence in the evaluative process. Losing bidders will be aware of the reasons behind their failure and will be able to improve future proposals; citizens will feel confident that the government secured the best possible deal for the project.

2. Mechanisms for the Preservation of the Incentive to Innovate

\section{a. Mechanisms}

According to private sector sources, firms are reluctant to submit unsolicited proposals for fear of a loss of control of their ideas without commensurate reward. The unique feature of this procurement model is that it incorporates a competitive process, while at the same time providing incentives for firms to engage in an innovative search for unsolicited targets. The model can include any of the following three mechanisms, regardless of whether an RFP-based or RFQ-based procurement process is initiated.

\section{i. Right of First Refusal}

The first mechanism that can be used to mitigate the effects of the competitive process on innovation is the right of first refusal. In the event that another proposal is selected, the initial proposer is granted the right to improve upon the winning proposal. This right would consist of a short (five to fifteen day) period in which details of the "winning" proposal are provided to the initial proposer, and a better proposal can be crafted. The initial proposer is thus unlikely to be beaten by mere price considerations. The short time limit, however, restricts the ability of the initial proposer to greatly modify his concept. This ensures that if the "winning" proposal is fundamentally different from the initial proposal, the "winner" does not run a large risk of losing. Bidders responding to RFQs or RFPs with innovative ideas of their own are thus also 
protected. The only way for a subsequent bidder to obtain the partnership is to have a more innovative idea that cannot be copied in such a short time period.

\section{ii. Price Protection}

Another method of safeguarding the incentive to submit unsolicited proposals is to guarantee price protection for the initial proposer. Price protection implies that in order to defeat the initial proposal, the cost savings or revenue generation from the winning bid must exceed the initial proposal by a minimum percentage (e.g. from 5 percent to 10 percent). While this technique is only relevant to those proposals which hinge on price/cost, its effect can be profound. By instituting a 5 or 10 percent cushion, the initial innovator will have some confidence that his innovative efforts will not be forfeited simply because another proposal may generate modestly greater savings or revenues. Fear of loss of proprietary information will be reduced because initial proposers will be aware that significant cost savings or revenue increases must be present for them to lose a bid.

\section{iii. Compensation}

The final technique, financial compensation, can be used when the initial proposer does not secure the public-private partnership, but the government acts on the unsolicited proposal and enters into a partnership with another firm. Currently, many bidding processes award honoraria to losing firms. The honorarium is based on an estimate of the cost of preparing a proposal. However, the amount of the honorarium often bears little relation to the actual cost of assembling the proposal. Additionally, in order to pay the honorarium, the government must make an immediate cash expenditure. ${ }^{84}$ Hence, by forcing the government to first approximate the cost of assembling a proposal and then pay honoraria, the cost savings generated by the partnership are immediately reduced.

Instead of paying honoraria, governments could offer to pay the initial proposer a sum of money that more accurately reflects the worth of the innovative idea. In order to reward the innovator for creating the idea, despite not being awarded the contract, the innovator could be awarded a small percentage of the savings that are realized on account of his innovation. Hence, if the innovator's idea is implemented and ultimately saves the government money (or generates revenue), a small percent (1 percent to 5 percent) of the savings/revenue could be paid to the innovator. Like a royalty, the firm responsible for the idea can reap the benefits, if the idea actually works. This eliminates the need to approximate the cost of assembling a proposal, and frees the government from any immediate capital expenditure. The money could be paid as the returns are generated. The important aspect of this type of reward is that it is not tied to the cost of the proposal, but is instead related to the actual performance of the innovation. include in the RFP the cost of paying honoraria to the losing bidders. As a result, the winning bidder has already factored in the cost of paying off the losers, and the government entity does not have to incur this immediate expense. However, this practice is not the norm in Canada. 
One shortcoming of this mechanism is that it can only reward an innovator for the loss of his proprietary technology in one jurisdiction. While the loss of the contract in the first jurisdiction may prevent the innovator from exploiting his innovation in other jurisdictions, the reward is indexed only to the savings/revenues generated in the first jurisdiction. Unfortunately, there is no way to compensate the initial proposer for the loss of this potential revenue.

\section{b. Difficulties With These Safeguards}

While the three safeguards enhance the incentive to engage in innovative search for unsolicited targets, they also create potential dangers. First, by offering a privilege to an innovator, these mechanisms create an incentive for firms to submit proposals, no matter how ill-considered, for every conceivable project. This incentive can be moderated through several requirements. Unsolicited proposals can have minimum content requirements in order to qualify for the privileges. Thus, the mere cost of assembling a sufficient proposal will act as a deterrent to submitting frivolous proposals. A related concern is that the privileges create an incentive to submit proposals for ideas that may not be acceptable for many years, but that might one day be considered. This problem can be remedied by providing that the privileges only apply if the government initiates the RFP/RFQ process within a certain time (one to two years) of the submission of the proposal.

In order to preserve the integrity of the system and ensure that all initial proposals receive the appropriate privileges, all proposals must be stored in an accurate and accessible filing system. By implementing a central body responsible for initial evaluation and storage of unsolicited bids, this can easily be achieved. Since one body would be responsible for both the evaluation and storage of these proposals, every time a proposal is submitted, it could be easily cross-referenced to verify that no other similar proposal has been submitted within the prescribed period of limitation (one to two years).

\section{c. Empirical Evidence}

Elements of the above model have begun to be implemented worldwide. First, the Department of Management and Budget of the State of Michigan has recently introduced a new program entitled "PERM," an acronym for "privatize, eliminate, retain or modify." Instead of either rejecting unsolicited bids or merely placing their authors on a list to receive a package should an RFP ever be initiated, Michigan initiated the PERM program. In that program, private sector firms are invited to "present a "business case' for why the state should privatize or outsource the activity or service." 85 The PERM Report outlines a model which stipulates the precise questions and issues that the private sector (or public sector) must address in its PERM business case. The concept involves a thorough analysis of the existing government function and an explanation regarding whether the government should privatize, eliminate, retain or 
modify the function. While Michigan has yet to stipulate a process for dealing with unsolicited proposals, it has at least recognized the value of unsolicited innovation and private sector expertise.

The aforementioned "modified-competitive model" is also adapted from some practices that occur in the Philippines. In Manila, upon receiving an unsolicited proposal, the government publishes the entire proposal in the newspaper and permits others to bid on the proposal for ninety days. The bids must undercut the initial proposal by 10 percent, and after ninety days the initial proposer has a right of first refusal. This method encourages unsolicited submissions and simultaneously incorporates a competitive process.

\section{B. MODEL II: REQUEST FOR CONCEPTUAL PROPOSALS (RFCP) ${ }^{86}$}

The broad-based request for conceptual proposals model entails one fundamental difference from the previous model. In this case, while the proposals are unsolicited in the sense that no specific projects have been identified, the process is initiated by the government. As such, the proposals are technically solicited, thus avoiding some of the confusion and surprise over purely unsolicited proposals, but by excluding any specific requirements, this model incorporates most of the elements of innovation common to purely unsolicited proposals. The model is characterized by the following statement:

No specific projects have been identified by the State. It is the responsibility of the companies and consortia participating in the second stage of this process to propose one or more projects that are believed to provide a reasonable rate of return in relation to the associated risk and investment, and provide improved transportation services within the State... There is no limitation on the size of the projects. Projects may be part of a larger development project or a separate project.... ${ }^{87}$

It is for this reason that the first stage of this process involves an internal decision to enter into a public-private partnership in order to utilize the private sector's financial, technological and operational innovations. Because the process is initiated by government, implementing this method of dealing with unsolicited proposals requires a fundamental policy alteration. Governments will have to commit personnel to discovering areas which could benefit from private sector involvement. While particular projects or solutions need not be identified, the government must be able to identify classes of functions that could potentially be better performed by the private sector.

\section{The Process}

\section{a. Identifying Areas to be Developed by Innovative Proposals}

The first stage in the process is identifying classes of government functions that could be developed or improved by private sector innovation. If a centralized

8. See Appendix B for diagrammatic representation.

${ }^{\prime}$ From California Department of Transportation, Office of Privatization, "Request for Qualifications for Toll Revenue Transportation Projects" (Sacramento, Ca.: November, 1989) [hereinafter California Request for Qualifications]. 
privatization committee is established, it would be the logical body to charge with the task of identifying appropriate targets for privatization. Currently, the most common government function that has been targeted in this manner has been transportation. ${ }^{88}$ Because transportation projects can range in size and complexity and generally involve large capital expenditures, they are ideal for this type of procurement. In addition, transportation projects are generally labour intensive and lengthy in duration, and thus generate spin-off economic benefits. These types of large infrastructure projects are thus attractive to government. However, the large financial obligations that they entail deter governments from undertaking them. By implementing private sector innovations, the same economic benefits can be achieved, and the government need not invest resources to identify the best project and undertake it. Therefore, many argue that this model is most appropriate for large infrastructure projects which would directly and indirectly enhance the economic condition of a given region, but which the government cannot afford.

\section{b. Creating a Request For Qualifications for Proponents} and Evaluating the Submissions

The Request for Qualifications, while an extremely brief document (4-6 pages), is in fact one of the most important components of this process. The Request for Qualifications is the private sector's first interface with the new concept of requesting innovative (quasi-unsolicited) bids for a given government function., Thus, while brief, the document should contain sufficient information to permit those companies who may be interested in pursuing the project to submit qualifications. In this document, the goals of the government must be clearly stated, and the precise request should be made clear. For example, the introduction to the California Department of Transportation's RFQ states:

The purpose of this RFQ is to select qualified and experienced companies or consortia who can design, obtain environmental approval, provide right of way, finance, construct, and operate toll revenue transportation projects (highway, bridge, tunnel, monorail, light rail, etc.) in the State of California without the use of state or federal funds.... The RFQ stage will allow the state to get to know you, your organization, your previous experience in constructing transportation facilities, and operating toll revenue projects, and your financial resources and capabilities to fund such projects. ${ }^{89}$

In addition to identifying the project and providing a general overview of what the government is seeking, the RFQ must specifically outline the information it needs to make a decision as well as the selection criteria according to which the decision will be made (and the respective weightings for each criterion). The RFQ might include a questionnaire to direct the responses of the various private sector firms. The questionnaire might explicitly address general information about the firm or consortium (identity, experience of leaders, structure, ownership, etc.), its financial capacity and its development experience.

88

For example, two major projects that have been initiated in this manner have been the California Department of Transportation's initiative (RFP issued in 1989) and the Washington State Department of Transportation's initiative (RFP issued in 1994).

89 California Request for Qualifications, supra note 87 at 2. 


\section{c. Creating a Broad Based Request for Conceptual}

Proposals and Evaluating the Submissions

Once a small number of qualified firms and/or consortia are selected to submit proposals, the government must create a formal Request for Conceptual Proposals (RFCP). This document should be more substantial than the RFQ, and should outline all of the rules that will govern the procurement process. It may be useful to include in this document a prohibition against lobbying, thus reducing concerns over corrupt dealings and enhancing public confidence in the process. Other provisions that the government deems to be important should be included in the RFCP. Most importantly, however, the RFCP should identify all criteria that the evaluators will use in assessing the various proposals, as well as their relative importance in the evaluation process.

Another useful clause that can be inserted into the RFCP is found in the Washington State Department of Transportation's 1994 Proposal Development Guidelines. The document states that, "[p]roposals must specifically identify any elements which are deemed confidential, or proprietary. Firms should be prepared upon request, to provide justification of why such materials should not be disclosed." 90

In this model, no proprietary information is revealed in the RFCP process. Because each firm receives the same broad information simply defining the area in which the projects are being sought (and perhaps their magnitude), each firm is free to create a totally innovative proposal, unencumbered by an RFP based on specific ideas. Hence, each organization's proposal will be unique and can remain proprietary without disadvantaging any of the other proposers. The disclosure of any proposal is not necessary for the process to proceed: proponents do not need access to each other's proposals in order to submit a proposal. For this reason, firms with innovative ideas that may be able to be implemented elsewhere should be permitted to demonstrate why there should be no compulsory disclosure.

\section{Empirical Evidence}

Of the two major transportation projects that have been mentioned in this section, the first, the California Department of Transportation's Toll-Road Initiative has already resulted in the successful construction of the first privately owned and operated tollroad built in the U.S. in fifty years. The California Private Transportation Corporation (led by Kiewit Infrastructure Ventures), in partnership with the Department of Transportation, has constructed SR-91, a ten mile toll-road. This project is the first fully-automated toll road in the world. Private sector innovation and financing has allowed the implementation of automatic vehicle identification technology. SR-91 is equipped with technology that communicates with a small transponder affixed near the rear-view mirror of each car, through which motorists pay tolls electronically. This automation will permit great flexibility in toll collecting. If this model is implemented correctly, the benefits to the public sector can be enormous. The public sector can have 
productive infrastructure constructed and operated without undertaking major financial expenditures. Economic benefits of state-of-the-art technology can be realized by taxpayers without committing major resources.

\section{MODEL III: MONITORED SOLE-SOURCING}

The final model posited by this article is a modified version of sole-sourcing, described in Part II of this article. Sole-sourced ventures are those public-private partnerships in which the private sector innovator is the only party with whom the government negotiates. According to many private sector proponents, sole-sourcing is the selection method most common for establishing public-private partnerships. They claim that sole-sourcing is not the result of a dislike of competition, but rather often results in a much better deal for both parties. They argue that,

if you're dealing with a knowledgeable client, you negotiate in good faith and you negotiate in a transparent format. You negotiate in a true mode of partnership, and not in an adversarial manner. If you don't negotiate fairly and openly you won't get another contract. There is a built-in incentive."

Sole-sourced projects can create large incentives for private sector firms to innovate. If the proponent of the innovative concept can provoke the government's interest, the innovator involved in a sole-sourced negotiation need not be concerned about the threat of competitors appropriating his ideas. Thus, the private sector innovator can concentrate all his efforts on perfecting the proposal and can negotiate in a partnership mode. By eliminating the threat of direct competition, the private sector is encouraged to invest resources in innovative searches for inefficiently managed government assets and functions.

Traditional sole-sourcing, however, has been problematic for the public sector. Afraid of accusations of patronage or favouritism, and committed to competition, government officials have been reluctant to utilize this procurement model outside of the four specific cases described in Part II. Despite the potential for forging a true partnership and reaping private sector efficiency benefits, sole-sourced projects have had limited use. The following discussion will thus incorporate principles identified and implemented in two recent sole-sourced ventures: Hamilton-Wentworth, Ontario and Philip Environmental's wastewater treatment partnership, and Franklin, Ohio and Wheelabrator EOS's water treatment venture. ${ }^{22}$

\section{When Can Sole-Sourcing be Useful?}

In order to determine what type of procurement model is appropriate, it is important to determine the goals of the project in question and to define the nature of both the relationship that exists between the parties and the one that is to be created. Solesourcing can have useful applications outside of the four cases described in Part II of this article. Often, obtaining the best price or the largest cost savings is the main driver 
of a given public-private partnership. However, sometimes public sector goals have a much broader scope. Sole-sourcing is generally most helpful in the latter situation. For example, the Hamilton-Wentworth/Philip Utilities Management Corp. wastewater project was in part initiated in order to stimulate regional development of an environmental services sector. The Hamilton-Wentworth Region did not merely want to contract out its wastewater management, but sought to establish Hamilton as a centre for environmental water and wastewater treatment technology.

According to proponents of that partnership, sole-sourcing should only be implemented in unique situations. ${ }^{93}$ In addition to having broad goals, the existence of an amicable relationship between the public sector and the private sector proposer is beneficial. In both the Hamilton-Wentworth and Franklin, Ohio projects, the municipalities had excellent prior relations with the private sector proposers. Because the strength of sole-sourcing is its ability to generate good relations between the parties, if the public sector is already aware of the accomplishments and culture of the private firm, it can make a decision in advance as to the compatibility of the two entities. In the Hamilton partnership, the Region had a long-standing relationship with Philip Environmental and its President, Dr. Stuart Smith. ${ }^{94}$ In the Franklin venture, Wheelabrator had been successfully managing the facilities for several years before privatization. In both cases, therefore, the public sector was familiar with the operational abilities and reputations of the private sector companies.

\section{Safeguarding the Sole-Sourcing Process}

Because sole-sourcing encourages creativity by safeguarding novel ideas from freeriding, its benefits can be realized by both parties in the form of more innovative proposals and in the form of agreements that are better tailored to the particular needs of the parties. While this procurement model is more useful where amicable relationships exist, it is still useful to incorporate into the sole-sourcing process some of the political safeguards afforded by the RFP process. The traditional criticism of sole-sourcing is the discrepancy in evaluative expertise that is believed to exist between the public and private sectors. Often taxpayers feel that the government must initiate competition in order to avoid being taken advantage of by an opportunistic private sector firm. In order to address this concern, governments involved in sole-sourcing should implement the following three safeguards.

\section{a. Independent Fairness Consultant}

In order to guarantee that the taxpayers' interests are being protected, the government should retain an independent consulting firm with substantial reputational capital at stake to evaluate the unsolicited, sole-sourced proposal. This should be done to ensure that the government gets a fair deal and is not "gamed" by the private sector proposer. This essential safeguard allows the government to reap the innovative benefits of

93 Interviews with Will Lipson, partner KPMG Management Consulting (July 1995) and with Mac Carson, Chair of Ontario Housing Corp. (25 June 1996).

94 President of Philip Utilities Management Corp., the management company that entered into partnership with Hamilton-Wentworth. 
unsolicited proposals by allowing it to negotiate fairly with firms that do not have to surrender their proprietary information.

In order to evaluate the proposals fairly, the faimess consultant should construct a list of criteria against which the proposal can be compared with existing public sector management and similar ventures in comparable situations (if they exist). In the Hamilton project, the absence of identical ventures forced KPMG to evaluate the proposal against fourteen similar projects located primarily throughout the United States. The Fairness Evaluation identified the relevant criteria for each project and thus provided guidelines by which to assess Philip's proposal. Because only one proposal (sole-source) is being evaluated, however, an absolute terms evaluation is impossible: no conclusion can be drawn that the proposal is the best one. Instead, the fairness evaluator must determine that the deal is a "fair" one for the region. Fairness must be determined on a balance of the risks and rewards.

\section{b. Impartial Mediator}

In order to safeguard the negotiation process, a mediator may need to be retained. In both the Hamilton and Franklin ventures, a "fairness consultant" was hired to ensure that the deal was beneficial to the public sector. ${ }^{95}$ Unfortunately, in both cases the consultant's role was obscured because of the dual nature of his tasks. In those negotiations, the third party consultant was asked to evaluate the proposal based on comparable ventures in order to ensure that the public sector was getting a good deal. However, in both cases the consultant was also required to act as a mediator throughout the negotiations. While in both cases no significant problems ensued, participants stated that a separate entity should be retained to act strictly as a mediator. By separating the roles of mediator and fairness evaluator, conflicts of interest can be eliminated and one entity can have the sole responsibility of ensuring that the negotiations are transparent, honest and fair. By retaining an independent party, agreed upon by both the public and private sectors, complaints about unfair negotiations should be eliminated.

\section{c. Statement of Requirements}

According to Donahue, "the more precisely a task can be specified in advance ... the more narrowly government cares about ends to the exclusion of means, the stronger becomes the case for employing profit-seekers rather than civil servants." ${ }^{196}$ The Statement of Requirements (SOR) is a document designed to "force the [public sector] to address issues that may not have been addressed or that may have been addressed only implicitly if an RFP had been issued. It force[s] internal debates which allow the region to go forward with a common stance and understanding." 97 The SOR is a document that is to be drafted by the public sector and its Fairness Consultant as soon as the proposal is received from the private sector (provided it is likely to be acted upon). It should be a comprehensive itemization of the public sector's position regarding

Hamilton-Wentworth retained Will Lipson, a partner at KPMG Management Consulting, and Franklin retained George Raftelis of Raftelis Environmental Consulting Group. 
the contracting or the operation of the service or asset in question. It can evolve throughout the negotiations as new elements arise and are deemed to be important by the public sector.

Government officials agree that the process of drafting the SOR forces them to consider all aspects of the deal, familiarize themselves with it, and decide what is most important. It acts, in part, as a record of the needs and wants of the public sector. In addition, it can create important incentives. If the negotiations continue past a previously agreed upon date, indicating an inability to agree, this document can be issued as an RFP. This provides an incentive to the private sector company to negotiate fairly and expeditiously, and enables the government easily to turn the process into a competitive one.

\section{CONCLUSION}

In fully exploiting the potential efficiency gains from public-private partnerships, unsolicited bids should play a critical role if information asymmetries, search costs, and bureaucratic and political incentives that presently constrain the possibilities for privatization and contracting are to be mitigated. A public sector counterpart to the private sector market for corporate control must be devised that shifts the burden of initiative from the public sector to the private sector. A well-defined, centralized process for the receipt and evaluation of unsolicited bids is required that is transparent in the evaluative criteria and decision-making processes employed so as to encourage private sector initiatives and to enhance public confidence in the integrity of the process. In designing such a process, special attention needs to be paid to preserving the incentives to innovate of first movers by mitigating the effect of free-riding by other bidders on the first mover's ideas in subsequent competitive tendering processes. This article has attempted to outline the nature of a process with these properties. While no doubt these proposals can be refined and adapted to different contexts, issues of process are integral to the success of the unsolicited bid concept. In turn, in the absence of a major role for unsolicited bids for the performance of public functions, the prospects for privatization or contracting out of government functions are likely to be sharply reduced. 


\section{APPENDIX A \\ MODIFIED COMPETITIVE PROCESS}

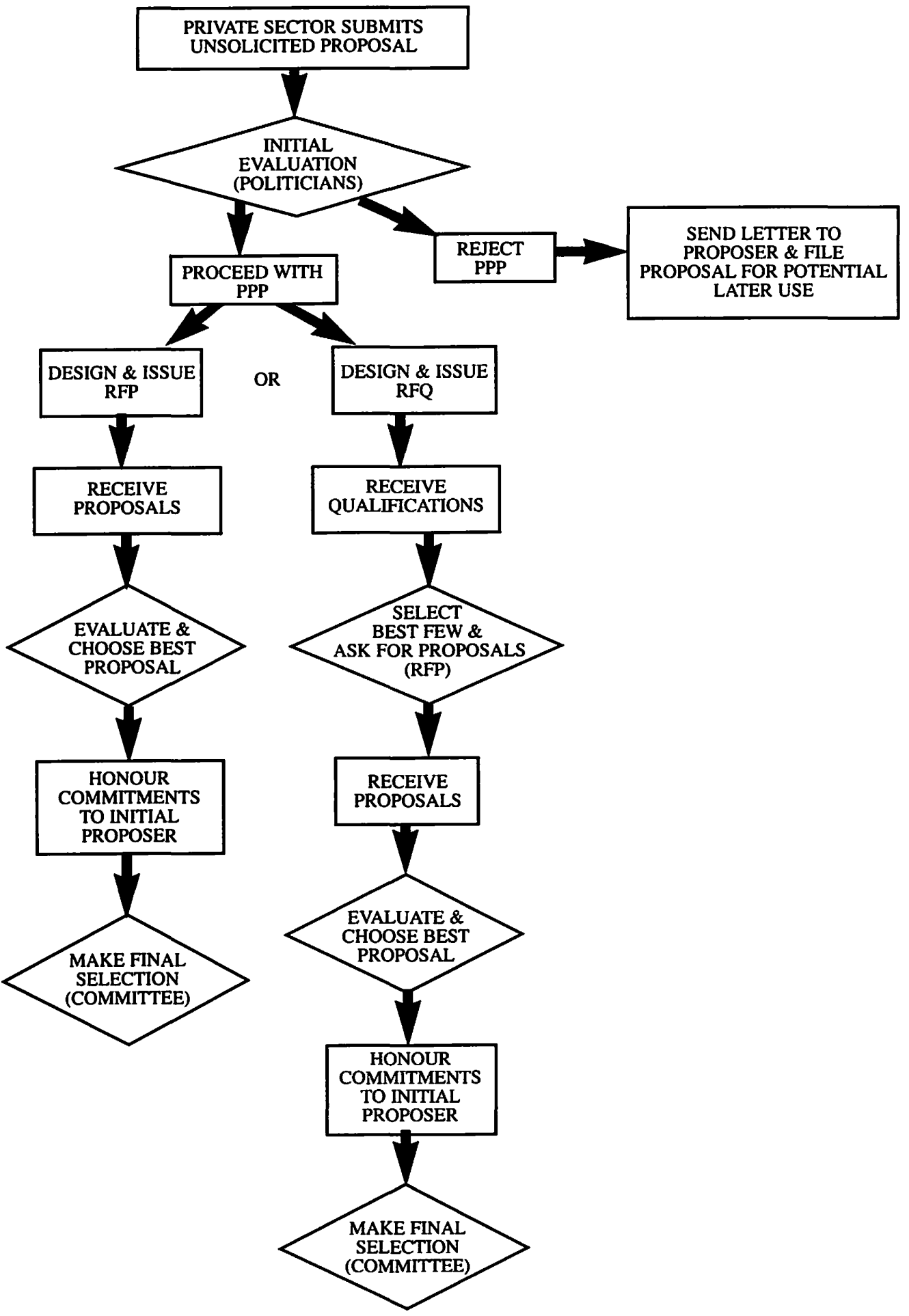


APPENDIX B

REQUEST FOR CONCEPTUAL PROPOSALS

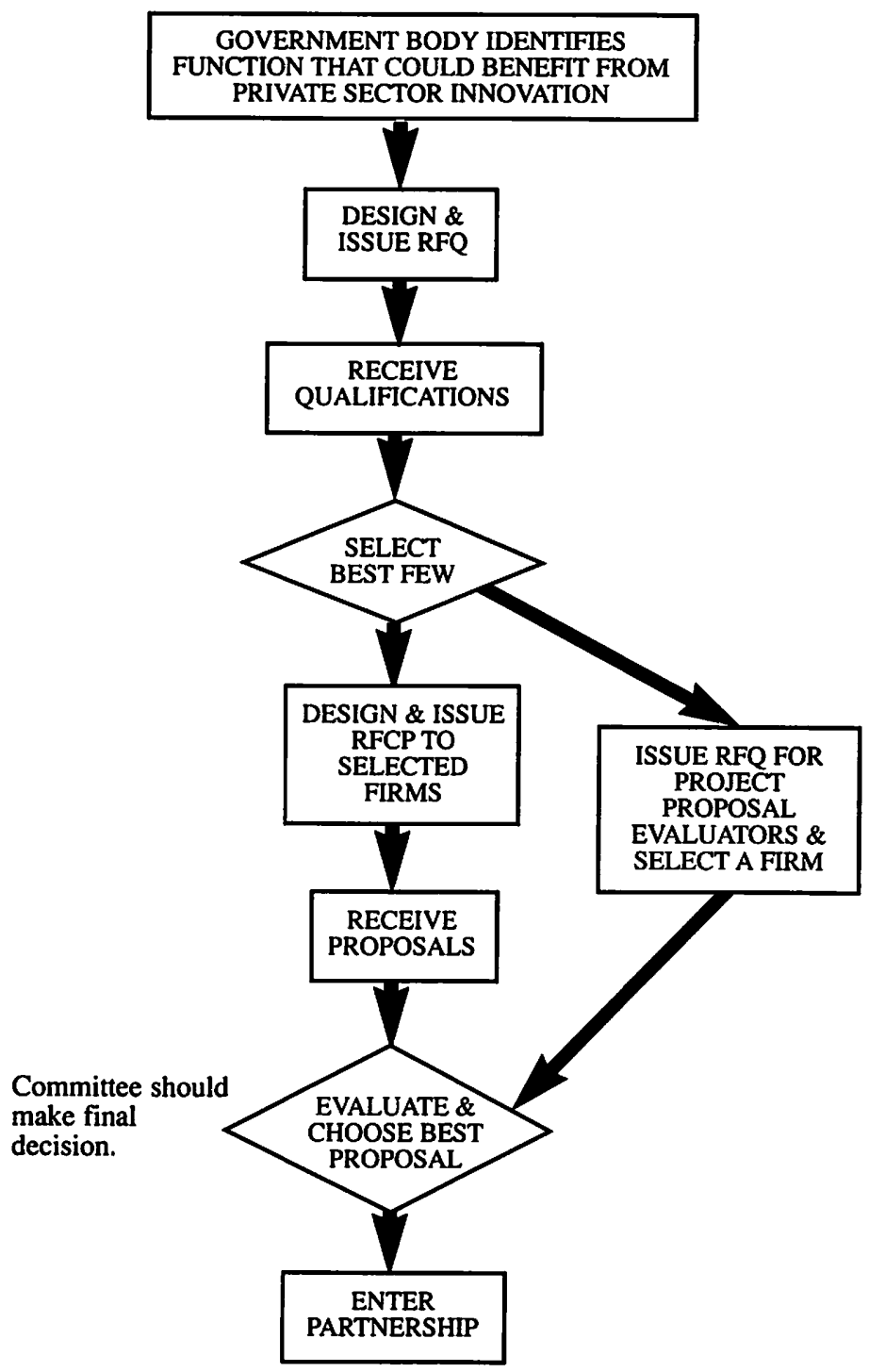

